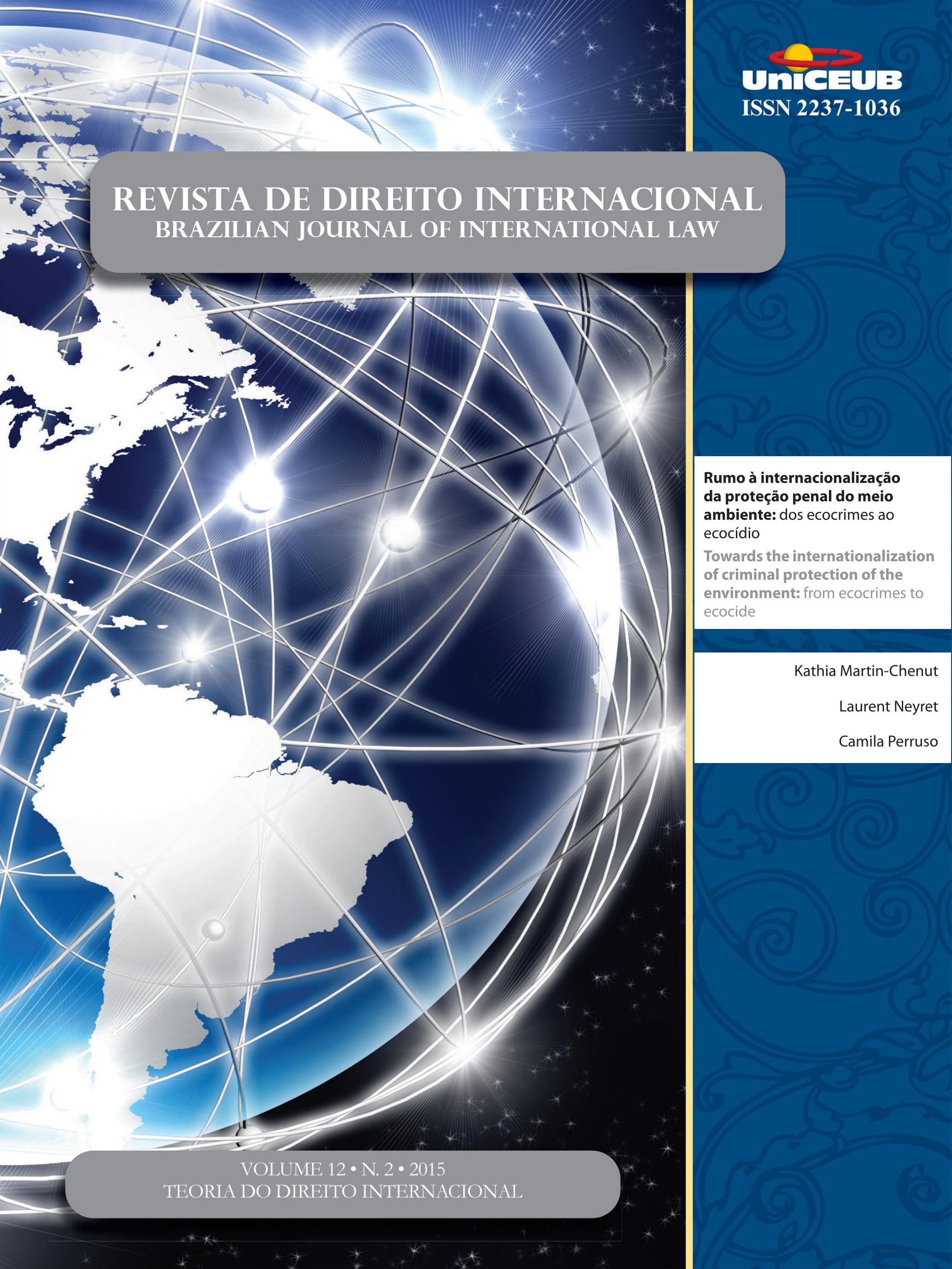




\section{Sumário}

CrôNiCAS DA ATUALIDADE do DiREITo INTERnACIONAL ..................................................... 2 Sarah Dayanna Lacerda Martins Lima, Carina Costa de Oliveira e Erika Braga

CrôniCas do Direito InternaCional dos InVESTIMENTOS ..............................................12 Nitish Monebhurrun

Por que voltar a Kelsen, o jurista do século XX ? 16 Inocêncio Mártires Coelho

O Princípio da Efetividade como conteúdo da norma fundamental (GrundNorm) DE KELSEN

Carlos Alberto Simões de Tomaz e Renata Mantovani de Lima

A JURIDIFICAÇÃo DE CONFLITOS POLÍTICOS NO DIREITO INTERNACIONAL PÚBLICO CONTEMPORÂ-

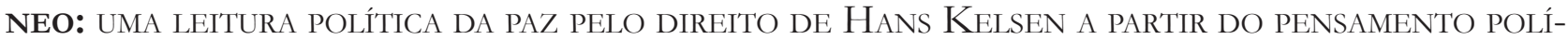
TICO De Claude Lefort

Arthur Roberto Capella Giannattasio

O SINCRETISMO TEÓRICO NA APROPRIAÇÃO DAS TEORIAS MONISTA E DUALISTA E SUA QUESTIONÁVEL UTILIDADE COMO CRITÉRIO PARA A CLASSIFICAÇÃO DO MODELO BRASILEIRO DE INCORPORA-

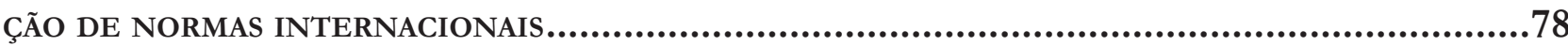
Breno Baía Magalhães

Direito Global em Pedaços: Fragmentação, Regimes e Pluralismo .98 Salem Hikmat Nasser

Por uma TeOria JURÍdica da INTEGRaÇão REgIONAL: A INTER-RELAÇÃO DiREITO INTERNO, DiREITO INTERNACIONAL PÚBLICO E DIREITO DA INTEGRAÇÃO Jamile Bergamaschine Mata Diz e Augusto Jaeger Júnior

A teOria DA INTERCONSTITUCIONALIDADE: UMA ANÁlISE COM BASE NA AMÉRICA LATINA...........160 Daniela Menengoti Ribeiro e Malu Romancini 
O DIÁLOGO HERMENÊUTICO E A PERGUNTA ADEQUADA À APLICAÇÃo DOS TRATADOS INTERNACIONAIS DE DIREITOS HUMANOS NO BRASIL: CAMINHOS PARA O PROCESSO DE INTERNACIONALIZAÇÃO

DA CONSTITUIÇÃO...................................................................................... 176

Rafael Fonseca Ferreira e Celine Barreto Anadon

O DIREITO COMPARADO NO STF: INTERNACIONALIZAÇÃO DA JURISDIÇÃO CONSTITUCIONAL BRASILEIRA

Carlos Bastide Horbach

THE PHILOSOPHY OF INTERNATIONAL LAW IN CONTEMPORARY SCHOLARSHIP: OVERCOMING NE-

GLIGENCE THROUGH THE GLOBAL EXPANSION OF HUMAN RIGHTS

Fabrício Bertini Pasquot Polido, Lucas Costa dos Anjos e Vinícius Machado Calixto

OpORTUNIDADES E DESAFIOS DAS TWAIL NO CONTEXTO LATINO-AMERICANO A PARTIR DE PERSPECTIVAS DOS POVOS INDÍGENAS AO DIREITO INTERNACIONAL

Fernanda Cristina de Oliveira Franco

Por Que uma ANÁlise ECONÔMICA Do DIREITO INTERNACIONAL PÚBLICO? DESAFIOS E PERSPECTIVAS DO MÉTODO NO BRASII

Gustavo Ferreira Ribeiro e Jose Guilherme Moreno Caiado

ANÁliSE ECONÔMICA do DIREITO INTERNACIONAL .263 Michele Alessandra Hastreiter e Luís Alexandre Carta Winter

RACIONALIDADE ECONÔMICA E OS ACORDOS BILATERAIS DE INVESTIMENTO 284 Michele Alessandra Hastreiter e Luís Alexandre Carta Winter

LOOKING FOR A BRICS PERSPECTIVE ON INTERNATIONAL LAW .304 Gabriel Webber Ziero

A INFLUÊNCIA DO DIREITO DESPORTIVO TRANSNACIONAL NO ORDENAMENTO JURÍDICO BRASILEIRO: DA REPRODUÇÃO DE NORMAS À APLICAÇÃO DIRETA PELA JURISDIÇÃO ESTATAL.......................3324 Tiago Silveira de Faria

CONVENCIONALIZAÇÃo DO DIREITO CIVIL: A APLICAÇÃo DOS TRATADOS E CONVENÇÕES INTERNACIONAIS NO ÂMBITO DAS RELAÇÕES PRIVADAS . 
NATIONAL JUdGES AND COURTS AS INSTITUTIONS FOR GLOBAL ECONOMIC GOVERNANCE 356

Juízes e tribunais nacionais como instituições para a governança global 356 Camilla Capucio

Is Trade Governance Changing? 371 Alberto do Amaral Júnior

OS FUNDOS ABUTRES: MEROS PARTICIPANTES DO CENÁRIO INTERNACIONAL OU SUJEITOS PERANTE O DIREITO INTERNACIONAL? 384

Guilherme Berger Schmitt

SHAREHOLDER AGREEMENTS IN PUBLICLY TRADED COMPANIES: A COMPARISON BETWEEN THE

U.S. AND BRAZIL. 402 Helena Masullo

REgulaÇÃo DO INVESTIMENTO ESTRANGEIRO DIRETO NO BRASIL: DA RESISTÊNCIA AOS TRATADOS BILATERAIS DE INVESTIMENTO À EMERGÊNCIA DE UM NOVO MODELO REGULATÓRIO 421 Fabio Morosini e Ely Caetano Xavier Júnior

DA QUALIFICAÇÃo JURÍDiCA dAS Distintas FORMAS DE PRESTAÇão TECNOLÓGICA: BREVE ANÁLISE DO MARCO REGULATÓRIO INTERNACIONAL

Daniel Amin Ferraz

REDEFINING TERRORISM: THE DANGER OF MISUNDERSTANDING THE MODERN WORLD'S GRAVEST THREAT

Jennifer Breedon

As EXECUÇões SELETIVAS E A RESPONSABILIZAÇÃo DE AGENTES TERRORISTAS 485 Alexandre Guerreiro

INTERNATIONAL CRIMINALS AND THEIR VIRTUAL CURRENCIES: THE NEED FOR AN INTERNATIONAL EFFORT IN REGULATING VIRTUAL CURRENCIES AND COMBATING CYBER CRIME Joy Marie Virga

Criminalidad transnacional organizada en el Ámbito del MERCOSUR: ¿Hacia un Derecho Penal Regional?. .528 Nicolás Santiago Cordini e Mariano Javier Hoet 
RUMO À INTERNACIONALIZAÇÃo DA PROTEÇÃO PENAL DO MEIO AMBIENTE: DOS ECOCRIMES AO ECOCÍDIO

Kathia Martin-Chenut, Laurent Neyret e Camila Perruso

Engaging the U.N. Guiding Principles on Business and Human Rights: the inter-AMERICAN COMMISSION ON HUMAN RIGHTS \& THE EXTRACTIVE SECTOR 571 Cindy S. Woods

O DIREITO HUMANO À COMUNICAÇÃo PRÉVIA E PORMENORIZADA DAS ACUSAÇÕES NOS PROCESSOS administrativos: O desprezo do Superior Tribunal de Justiça ao Pacto de San José da Costa Rica e À Corte Interamericana de Direitos Humanos .590

Daniel Wunder Hachem e Eloi Pethechust

A responsabilidade internacional do Brasil em FaCe do CONTRole de ConVENCionaliDADE EM SEDE DE DIREITOS HUMANOS: CONFLITO DE INTERPRETAÇÃO ENTRE A JURISDIÇÃO DA Corte Interamericana de Direitos Humanos e o Supremo Tribunal Federal quanto a LEI DE ANISTIA 612

Carla Ribeiro Volpini Silva e Bruno Wanderley Junior

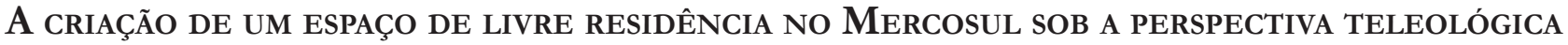
DA INTEGRAÇÃo REGIONAL: ASPECTOS NORMATIVOS E SOCIAIS DOS ACORDOS DE RESIDÊNCIA ....... 631

Aline Beltrame de Moura

A funcionalização como tendênCia evolutiva do Direito Internacional e sua conTRIBUIÇÃO AO REGIME LEGAL DO BANCO DE DADOS DE IDENTIFICAÇÃO DE PERFIL GENÉTICO NO BRASIL

Antonio Henrique Graciano Suxberger

O DIREITO INTERNACIONAL E A PROTEÇÃO DOS DIREITOS DE CRIANÇAS E DE ADOLESCENTES EM CONFLITO COM A LEI EM MOÇAMBIQUE

Bernardo Fernando Sicoche

ObTenÇão de PRovas no EXTERIOR: PARA ALÉM dA LEX FORI E LEX DiLigENTIAE. .685 André De Carvalho Ramos 
A Slight Revenge and a Growing Hope for Mauritius and the Chagossians: The UNClos Arbitral Tribunal's Award of 18 March 2015 on Chagos Marine Protected Area (Mauritius v. United Kingdom)

Géraldine Giraudeau

ANÁLISE DA RESPONSABILIDADE INTERNACIONAL DA UCRÂNIA POR VIOLAÇÃo DOS DIREITOS HUmanos na QUeda do voo da Malaysia Airlines (MH17). .728

Daniela Copetti Cravo

NatureZa JURÍdica do DESENVOLVIMENTO SUSTENTÁVEL No DIREITO INTERNACIONAL ........739 Pedro Ivo Diniz

A INFLUÊNCIA Da SOFT LAW NA FORMaÇão do DiREITo AMBIENTAL .767 Leonardo da Rocha de Souza e Margareth Anne Leister

As COMPLICADAS INTER-RELAÇÕES ENTRE OS SISTEMAS INTERNOS E INTERNACIONAIS DE PROTEÇãO DO DIREITO AO MEIO AMBIENTE SADIO. 785 José Adércio Leite Sampaio e Beatriz Souza Costa 


\title{
Rumo à internacionalização da proteção penal do meio ambiente: dos ecocrimes ao ecocídio*
}

\author{
Towards the internationalization of criminal \\ protection of the environment: from \\ ecocrimes to ecocide
}

Kathia Martin-Chenut ${ }^{* *}$

Laurent Neyret ${ }^{* * *}$

Camila Perruso****

* Recebido em 15/11/2015

Aprovado em 08/12/2015

** Pesquisadora do CNRS - Conselho Nacional de Pesquisa Científica - França. Codiretora da Equipe RSE UMR DRES 7453 e da pesquisa IdEx Attractivité - "Responsabilité Sociétale des Entreprises: identification et classement des outils juridiques" - (http:// dres.misha.cnrs.fr/spip.php?rubrique193). Corresponsável do módulo Law and Politics of International Courts and Tribunals do LL.M in International Law na Universidade Paris Descartes. E-mail: kmartinchenut@orange.fr.

*** Professor na Universidade de Versailles Saint Quentin - França. Diretor da pesquisa Ecocide - Mission Droit et Justice (GIP-Ministério da Justiça da França). E-mail: neyret.1@ wanadoo.fr.

**** Doutoranda em direito internacional pelas Universidades Paris Descartes e de São Paulo. Assistente de ensino e de pesquisa A.T.E.R e corresponsável do módulo Law and Politics of International Courts and Tribunals do LL.M in International Law na Universidade Paris Descartes. Pesquisadora do projeto IdEx Attractivité - "Responsabilité Sociétale des Entreprises: identification et classement des outils juridiques”. E-mail: camilaperruso@gmail.com.

\section{Resumo}

O presente artigo busca analisar o necessário movimento de apreensão da proteção penal do meio ambiente pelo direito internacional de maneira gradual e racional. Por meio da identificação das lacunas existentes nesse ramo do direito, são tecidas proposições capazes de lutar contra a criminalidade ambiental que põe em perigo a segurança do planeta, inscritas nos projetos anexos de Convenção sobre a ecocriminalidade e o ecocídio. Nesse sentido, uma renovação da ordem jurídica internacional que funda, ao lado do respeito dos direitos humanos, a proteção do meio ambiente constitui uma tendência legítima e que se inscreve em um processo de evolução dos valores comuns compartilhados pela humanidade.

Palavras-chave: Criminalidade ambiental. Direito internacional. Segurança ambiental do planeta. Intervenção penal mínima.

\section{Abstract}

This article aims to analyze the necessity to take into account the criminal protection of the environment in international law, gradually and rationally. By identifying existing gaps in this branch of law, propositions were made regarding to fight against environmental crime that endangers the safety of the planet, as it is expressed in the Convention projects on ecocriminality and ecocide attached. In this sense, a renewal of international law founded in the respect of human rights and also in the environmental protection is a legitimate process of evolution of the common values shared by humanity.

Keywords: Environmental crime. International law. Environmental security of the planet. Minimal penal intervention. 


\section{INTRODUÇÃO}

A degradação do meio ambiente apresenta-se como um desafio a diversas áreas do conhecimento, visto que os avanços proporcionados pelo progresso das ciências implicaram as necessidade de uma tomada de consciência das sociedades modernas da contradição existente entre um desenvolvimento desmedido em relação à sustentabilidade do planeta. $\mathrm{O}$ aumento das atividades humanas, visando ao crescimento econômico - muitas vezes confundido com o desenvolvimento -, aliado ao avanço da tecnologia, tem gerado impactos ambientais como a poluição, a deflorestação, as ameaças à biodiversidade e as mudanças climáticas, de maneira a exigir que a exploração pelo homem do seu babitat seja reexaminada.

Nessa perspectiva, o meio ambiente adquiriu um valor superior, considerando que sua proteção encontra seus fundamentos na segurança da humanidade presente e futura, e mais amplamente na segurança do planeta e do equilíbrio ecológico. O compartilhamento do valor atribuído ao meio ambiente pela comunidade internacional designa uma "profunda renovação dos valores essenciais, cuja violação gera uma reprovação social"1. Justifica-se, nesse ensejo, a necessidade da consagração, em direito internacional, de uma proteção penal do meio ambiente, sobretudo em virtude da disparidade das disposições nacionais e internacionais existentes visando reprimir a criminalidade ambiental.

Dessa maneira, ao mesmo tempo em que o meio ambiente passa a ser objeto de importância primordial para a comunidade internacional ${ }^{2}$, constata-se que a criminalidade ambiental ocupa o quarto lugar no âmbito internacional de atividades econômicas ilícitas, perdendo, apenas, para o tráfico de drogas, de pessoas e de objetos falsificados. Trata-se de um tipo de criminalidade caracterizada pela transnacionalidade, que permite um elevado lucro face aos baixos riscos que sofrem seus autores, considerando que a persecução e a sanção de

1 DELMAS-MARTY, Mireille. Perspectives ouvertes par le droit de l'environnement. Revue Juridique L'Environnement, Paris, v. 39, p. 7-13, 2014. Numéro spécial: Le droit répressif: quelles perspectives pour le droit de l'environnement. p. 7.

2 Diversos instrumentos internacionais têm sido adotados com vistas a estabelecer uma proteção do meio ambiente. O desenvolvimento do direito internacional do meio ambiente encontra, na adoção da Declaração de Estocolmo de 1972, um ponto crucial contribuindo à proliferação de recomendações e de convenções desse ramo do direito internacional. tais atos são raros (“low risk - bigh profit") $)^{3}$.

Por criminalidade ambiental, ou ecocriminalidade, compreende-se os "crimes que ameaçam ou prejudicam o meio ambiente, que tenham ou não repercussões sobre o homem"4. Tais crimes podem variar de uma escala de infração isolada que não engendra consequências maiores à integridade ambiental, até o crime de ecocídio que ameaça a vida humana e a segurança planetária. Nesse sentido, por "crimes comuns", contra o meio ambiente, é possível pensar na caça furtiva, no descarte de efluentes agrícolas em um rio, no abandono ilegal de resíduos na natureza. Tais crimes podem ser cometidos em virtude de ações ou omissões, de comportamentos intencionais ou negligentes, realizados por pessoas físicas ou morais, além de serem produzidos no âmbito de território nacional ou transgredir fronteiras, como também no quadro de atividades transnacionais ilícitas.

No que se refere aos "crimes fora do comum", identificam-se os comportamentos excepcionais que engendram danos irreversíveis e de extrema gravidade ao meio ambiente, que podem ocorrer em tempos de guerra ou de conflito armado ${ }^{5}$, como por exemplo a uti-

3 Comunicação da Comissão europeia sobre a abordagem adotada pela União europeia em matéria de luta contra o tráfico de espécies selvagens COM(2014) 64 final. Cf. EUROPEAN UNION'S JUDICIAL COOPERATION UNIT. Strategic Project on Environmental Crime: report. Haag: Eurojust, Nov.2014. p. 38 Available in: <http://www.eurojust.europa.eu/doclibrary/eurojust-framework/ casework/strategic $\% 20$ project $\% 20$ on $\% 20$ environmental $\% 20$ crime $\% 20$ (october $\% 202014$ )/environmental-crime-report_201411-21-en.pdf>. Access: Feb. 02, 2016. Cf. NEYRET, Laurent. La criminalité environnementale c'est gros profits pour petits risques. Disponible dans: <http://www.europe1.fr/emissions/europe-1-vous-repond/ neyret-la-criminalite-environnementale-cest-gros-profits-pour-petits-risques-2617361>. Accès: 02 Fev. 2016.

4 FOUCHARD, Isabelle; NEYRET, Laurent. 35 propositions pour mieux sanctionner les crimes contre l'environnement. In: NEYRET, Laurent (Dir.). Des écocrimes à l'écocide: le droit pénal au secours de l'environnement. Bruxelles: Bruylant, 2015. p. 305-442, p. 315. Verificar artigo XX da Proposição anexa de Convenção para os ecocrimes.

5 Estatuto de Roma do Tribunal Penal Internacional, A/CONF. 183/ 9, 17 de julho de 1998, artigo 2: "para os efeitos do presente Estatuto, entende-se por "crimes de guerra": b) Outras violações graves das leis e costumes aplicáveis em conflitos armados internacionais no âmbito do direito internacional, a saber, qualquer um dos seguintes atos: iv) Lançar intencionalmente um ataque, sabendo que o mesmo causará perdas acidentais de vidas humanas ou ferimentos na população civil, danos em bens de caráter civil ou prejuízos extensos, duradouros e graves no meio ambiente que se revelem claramente excessivos em relação à vantagem militar global concreta e direta que se previa”. NAÇÕES UNIDAS. Tribunal Penal Internacional. Estatuto de Roma. Disponível em: <http://www.un.org/ spanish/law/icc/statute/spanish/rome_statute(s).pdf>. Acesso 
lização do agente laranja durante a guerra do Vietnã, ou em tempos de paz, com atos ilícitos como o tráfico de recursos naturais e de espécies ou de substâncias perigosas como as pesticidas. Esse último tipo de criminalidade ambiental, se preencher as condições necessárias para sua qualificação como ecocídio ${ }^{6}$, é aquele que gera consequências dramáticas para as populações locais na medida em que as expõe a graves riscos sanitários. Ademais, tais atos dizem respeito a toda humanidade, visto que suas condições de existência e de desenvolvimento, das gerações presentes e futuras, são colocadas em perigo.

Partindo da constatação de que a criminalidade ambiental é um problema premente e visto que a proteção do meio ambiente é um dos imperativos atuais da comunidade internacional, uma pesquisa ${ }^{7}$ tendo como objetivo apresentar soluções jurídicas a tal fenômeno foi realizada na França. Reunindo dezesseis pesquisadores de diversas disciplinas do direito e pertencentes a diferentes tradições jurídicas, a pesquisa foi desenvolvida entre 2011 e 2014 e financiada pela Missão de Pesquisa Direito e Justiça (GIP - Ministério da justiça francês), contando ademais com o suporte de campo

em: 01 fev. 2016.

6 Verificar os elementos constitutivos do crime de ecocídio no artigo 2 da Proposição anexa de Convenção para o crime de ecocídio. O termo ecocídio, que etimologicamente faz referência ao genocídio (genos, raça em grego e occidio, massacre, carnificina), significa destruição do ecossistema. Ele foi empregado, pela primeira vez, em 1970 em uma conferência em Washington, relativa à guerra e à responsabilidade em razão da situação hostil na Indochina e no Vietnam. No ensejo desse encontro, R. Falk cunhou essa expressão por meio da elaboração de um primeiro projeto de convenção, visando que os Estados reconhecessem o ecocídio como crime internacional. Para o autor, o ecocídio seria qualificado a partir dos atos humanos que destruiriam os ecossistemas, em todo ou em parte, em tempos de guerra ou em tempos de paz (FALK, Richard. Environment warfare and ecocide: facts, appraisal and proposals. Révue Belge de Droit International, Brussels n. 11, p. 1-27, 1973. p. 21-24). Essa preocupação foi apreendida pela Subcomissão para a prevenção da discriminação e proteção de minorias da Organização das Nações Unidas (ONU) que, em 1979, cogitou inserir no escopo do crime de genocídio a proteção do meio ambiente (Relatório The Study on the Question of the Prevention and Punishment of the Crime of Genocide, E/CN.4/Sub.2/416, 4 de julho de 1979). Para um estudo dedicado à noção de ecocídio: NEYRET, Laurent. Pour la reconnaissance du crime d'écocide, Paris, v. 39, p. 179-194, 2014. Numéro spécial: Le droit répressif: quelles perspectives pour le droit de l'environnement.

7 f. NEYRET, Laurent. Des écocrimes à l'écocide, un groupe de juristes au secours de l'environnement. In: In: BRÉCHIGNAC, Catherine; BROGLIE, Gabriel de; DELMAS-MARTY, Mireille (Dir). L'environnement et ses métamorphoses. Paris: Hermann, 2015. p. 183-193. de uma equipe de jornalistas do Jornal Le Monde $e^{8}$ que investigaram em mais de dez países diferentes as rotas da criminalidade ambiental transnacional, enquetes que permitiram confrontar aos fatos a necessidade do desenvolvimento de um arcabouço jurídico internacional capaz de reprimir os graves danos ao meio ambiente. Nesse sentido, duas proposições de projeto de convenção internacional tratando dos crimes contra o meio ambiente foram elaboradas (conferir documentos anexos), visando à adaptação do direito penal às particularidades das duas categorias de criminalidade ambiental internacional estabelecidas: ecocrimes e ecocídio.

O presente artigo busca apresentar os resultados dessa pesquisa acadêmica, analisando as lacunas existentes em direito internacional relativas à criminalidade ambiental (1), e propondo em consequência que um regime jurídico comum, gradual e racional seja estabelecido em direito internacional com vistas a uma efetiva proteção penal ambiental (2).

\section{A IMPOTÊNCIA ATUAL DO DIREITO INTERNACIO- NAL NO TOCANTE À CRIMINALIDADE AMBIENTAL}

A criminalidade ambiental apresenta diversas faces que afetam as sociedades como um todo e faz parte da categoria de riscos globais. Ela tem consequências não somente ambientais, mas impacta os âmbitos sanitário, econômico e pode ter implicações na segurança de determinados países, como atestam casos emblemáticos de conflitos relacionados à degradação ambiental (2.1). A dificuldade de atribuir a responsabilidade dos autores dessa criminalidade evidencia as lacunas existentes em direito internacional, cujos instrumentos existentes revelam-se insuficientes. Observa-se, adicionalmente, que uma grande parte das atividades ilícitas têm, preeminentemente, em sua origem, a ação de empresas transnacionais, o que confirma a incapacidade de o direito internacional atual oferecer respostas adequadas a tal fenômeno (2.2).

8 Cf.: MARTIN-CHENUT, Kathia; FOUCHARD, Isabelle. Quelles responsabilités pour les sociétés transnationales? Le Monde, Paris, 8 Fev. 2015. Disponible à: <http://www.lemonde. $\mathrm{fr} /$ planete/visuel/2015/01/24/ecocide-episode-1-le-bois-quisaigne_4527270_3244.html\#sDDxAh2Sz0KV7qjS.99>. Accès: 2 Fev. 2015. E LE MONDE. Les Prédateurs: la nature face au crime organisé. Paris: Ateliers Henry Dougier, 2015. 


\subsection{Uma necessidade crescente de apreender a criminalidade ambiental pelo direito internacional}

Os crimes relacionados ao meio ambiente são identificados em nível internacional notadamente em razão das redes criminosas que envolvem diversos países. A título de ilustração, o comércio ilegal de madeira rosa do Madagascar ${ }^{9}$ conhece um grande sucesso dos compradores chineses, assim como o tráfico do chifre de rinocerontes de Moçambique ${ }^{10}$. Esse tipo de tráfico conta com importantes organizações criminosas, envolvendo diferentes países e pessoas de múltiplas nacionalidades.

Além dos impactos desse tipo de crime sobre a biodiversidade e o equilíbrio ecológico, os riscos relacionados aos atos criminosos têm, também, um alcance sanitário, pois é frequente que a saúde humana e mais amplamente toda a humanidade sejam submetidas aos efeitos prejudiciais causados pela degradação ambiental. Por exemplo, a descarga ilegal de lixo tóxico na Costa do Marfim por uma empresa holandesa, no famoso caso do "Probo Koala"11, teve graves repercussões ambientais, como a contaminação de águas, de solos e de ar, mas também humanas, visto que ele provocou a morte de 17 pessoas e intoxicou mais de 50.000 pessoas e não culminou na responsabilidade penal de nenhum dos agentes envolvidos.

Verifica-se que a criminalidade ambiental é intrinsecamente ligada a questões econômicas e a violação da legislação correspondente se funda na busca por uma relação

9 MARTIN-CHENUT, Kathia; FOUCHARD, Isabelle. Quelles responsabilités pour les sociétés transnationales? Le Monde, Paris, 8 Fev. 2015. Disponible à: <http://www.lemonde. $\mathrm{fr} /$ planete/visuel/2015/01/24/ecocide-episode-1-le-bois-quisaigne_4527270_3244.html\#sDDxAh2Sz0KV7qjS.99>. Accès: 2 Fev. 2016.

10 Cf. MOZAMBIQUE: le trafic à grande échelle d'ivoire et de cornes de rhinocéros continue. Le Monde, Paris, 14 Mai. 2014. Disponible à: <http://www.lemonde.fr/afrique/article/2015/05/14/ mozambique-le-trafic-a-grande-echelle-d-ivoire-et-de-cornes-derhinoceros-continue_4633777_3212.html>. Accès: 2 Fev. 2016.

11 Cf. QUEINNEC, Yann. L'affaire Probo Koala, symbole d'une responsabilité sociétale des entreprises en quête de sécurité juridique. In: GUIDICELLI-DELAGE, Geneviève; S. MANACORDA, Stefano (Dir.). La responsabilité pénale des personnes morales: perspectives européennes et internationales. Paris: Société de législation comparée, 2013. (Unité mixte de recherche de droit comparé de Paris; v. 30). p. 277-293; dossiê do caso elaborado pela Anistia internacional: AMNESTY INTERNATIONAL. Côte d'Ivoire: une vérité toxique. à propos de trafigura, du probo koala et du déversement de déchets toxiques en Côte d'Ivoire. 25 Sep. 2012. Disponible dans: <http:// www.amnesty.org/fr/documents/AFR31/002/2012/fr/>. Accès: 02 Fev. 2016. custo-benefício. Nessa direção, baseando-se em um dumping ambiental, o tráfico de lixo tóxico pode custar dez vezes menos que reciclá-lo no país de produção. E como as sanções são fracas e pouco visadas pela comunidade internacional assim como pelos Estados nacionais, o mercado criminal ambiental é muito mais lucrativo que se comparado, por exemplo, ao tráfico de drogas.

Ademais, a ecocriminalidade cometida em determinados países em desenvolvimento, notadamente africanos, diz respeito a questões de ordem da segurança nacional. A ONU e a Interpol apontam que o dinheiro dos crimes ambientais relacionado às redes organizadas pode servir a financiar grupos rebeldes ou movimentos terroristas. Existem conexões entre os conflitos armados na África e os recursos naturais, como a questão do "diamante de sangue" no Congo e a consequente desestabilização de regiões inteiras, que mostram o importante alcance geopolítico da criminalidade ambiental; ela pode assim constituir uma ameaça para a segurança nacional e para a paz.

Diante desse panorama, observa-se que os direitos nacionais são inadaptados para lidar com a criminalidade ambiental, em razão especialmente do seu caráter transnacional. Embora o direito penal como instrumento de proteção do meio ambiente tenha se desenvolvido em diversos Estados, constata-se que, de um modo geral, a legislação penal refere-se a infrações penais acessórias, subordinadas ao não respeito de regras administrativas. Além disso, verifica-se que as infrações ambientais autônomas encontram-se, também, previstas nos ordenamentos penais internos a título de crimes comuns $^{12}$ ou ainda de crimes fora do comum ${ }^{13}$. Todavia, embora direitos penais nacionais específicos à criminalidade ambiental existam, sua aplicação varia de acordo com o Estado. A disparidade do nível das sanções favorece um verdadeiro dumping ambiental e serve de catalisador para as atividades criminais. Nessa perspectiva, para que a luta contra a ecocriminalidade transnacional seja efetiva, uma harmonização das incriminações e das

12 Cf. ESTUPIÑAN-SILVA, Rosmerlin. La lutte contre la criminalité environnementale au sein des Etats. In: NEYRET, Laurent (Dir.). Des écocrimes à l'écocide: le droit pénal au secours de l'environnement. Bruxelles: Bruylant, 2015. p. 19-38.

13 Quanto aos "crimes fora do comum", notadamente o crime ecocídio, ele foi incorporado em mais de dez códigos penais de Estados, como o Vietnã, a Rússia e as antigas repúblicas soviéticas, nos quais ele é geralmente definido como o fato de destruir massivamente a flora e a fauna, de contaminar a atmosfera, as águas, e mais amplamente todo ato capaz de causar uma catástrofe ecológica. 
sanções penais entre os Estados evidencia-se necessária.

\subsection{As lacunas do direito internacional em ma- téria de criminalidade ambiental}

Se o direito internacional do meio ambiente é considerado um "direito promocional", centrado em mecanismos de prevenção, sua efetividade é constantemente questionada, sobretudo em razão das sanções correspondentes às obrigações que ele determina. Não existe a previsão de um crime ecológico geral e os instrumentos que preveem uma sanção penal a infrações setoriais encontram-se em convenções esparsas ${ }^{14}$. $\mathrm{O}$ aspecto penal do direito internacional ambiental evolui de maneira incoerente e em função de imperativos estabelecidos pela agenda diplomática dos Estados.

Assim, a questão da poluição, um dos principais aspectos prejudiciais ao meio ambiente, é considerada uma infração somente no âmbito dos mares e rios ${ }^{15}$. Além dos prejuízos diretos ao meio ambiente, há previsão em direito internacional da penalização de determinados atos que ameaçam o ecossistema, como o tráfico de resíduos perigosos e seu depósito ${ }^{16}$ ou ainda o comércio de espécies selvagens da flora e da fauna ameaçadas de extinção ${ }^{17}$. Todavia, tais obrigações de penalização são imprecisas, visto que os textos conferem uma margem de manobra importante aos Estados para sancionar os prejuízos ao meio ambiente, por meio de incriminações indiretas e fazendo referência à obrigação de "tomar medidas apropriadas" ou de "reprimir severamente",

14 BEAUVAIS, Pascal. Les limites de l'internationalisation du droit pénal de l'environnement. In: NEYRET, Laurent (Dir.). Des écocrimes à l'écocide: le droit pénal au secours de l'environnement. Bruxelles: Bruylant, 2015. p. 3-18. p. 5-11.

15 Convenção Internacional para a Prevenção da Poluição por Navios, Convenção Marpol, de 17 de fevereiro de 1973. CONVENÇÃO Internacional para a Prevenção da Poluição por Navios (MARPOL 73/78). 1973. Disponível em: <http://www.fd.unl.pt/ docentes_docs/ma/jc_MA_26322.pdf >. Acesso em: 01 fev. 2016.

16 Convenção de Basiléia. Controle dos Movimentos Transfronteiriços de Resíduos Perigosos e seu Depósito de 22 de março de 1989. CONVENÇÃO de Basileia e controle de movimentos transfronteiriços de resíduos perigosos e sua eliminação. 1989. Disponível em: <http://www.ecomodus.eu/downloads/Basel_Conventionpt.pdf>. Acesso em: 01 fev. 2016.

17 Convenção sobre o Comércio Internacional das Espécies da Fauna e da Flora Selvagens Ameaçadas de Extinção, CITES, de 23 de março de 1973. CONVENÇÃO Sobre o Comércio Internacional das Espécies Selvagens da Fauna e da Flora Ameaçadas de Extinção. 1973. Disponível em: <http://eur-lex.europa.eu/legalcontent $/ \mathrm{PT} / \mathrm{TXT} / \mathrm{PDF} /$ ?uri=CELEX:22015A0319(01)\&from= PT>. Acesso em: 01 fev. 2016. ou ainda a previsão de regras de coordenação entre os Estados dessa repressão é praticamente inexistente ${ }^{18}$.

De acordo com a repartição clássica entre o direito internacional e o direito interno no que se refere à criminalização de condutas, é necessário que seja desenvolvido no âmbito interno uma ação normativa a fim de incorporá-la no ordenamento jurídico nacional e torná-la efetiva, visto que a aplicação da norma internacional em matéria criminal não é imediata. Mas, como as determinações do direito internacional relativo à penalização dos danos ambientais é vaga, a atribuição da responsabilidade assim como as penas aplicáveis às infrações também o são. Nesse contexto de criminalidade ambiental transnacional, o direito internacional não oferece nenhuma precisão quanto aos modos de imputação do crime e, consequentemente, os agentes podem ficar ilesos à responsabilização.

Existe, assim, uma carência em direito internacional do tratamento global da criminalidade ambiental e com a ausência de um órgão internacional ${ }^{19}$ competente para verificar e julgar tais crimes, é possível inferir que tais lacunas abrem brechas para um tratamento assimétrico da repressão da ecocriminalidade. A responsabilização dos agentes constitui, dessa maneira, um ponto sensível e o fórum shopping conhece, no campo ambiental, um franco sucesso ${ }^{20}$. É prática recorrente que as empresas multinacionais transfiram suas atividades a países onde a legislação ambiental é mais permissiva. Esse fenômeno dificulta e, geralmente, impede que elas sejam responsabilizadas caso cometam graves danos ao meio ambiente ${ }^{21}$. Nessa perspectiva, a responsabilização penal dos atores privados face aos danos ecológicos é essencial ${ }^{22}$.

18 BEAUVAIS, Pascal. Les limites de l'internationalisation du droit pénal de l'environnement. In: NEYRET, Laurent (Dir.). Des écocrimes à l'écocide: le droit pénal au secours de l'environnement. Bruxelles: Bruylant, 2015. p. 3-18. p. 14.

19 Com exceção da CPI no quadro do crime de guerra supra mencionado.

20 MARTIN-CHENUT, Kathia; FOUCHARD, Isabelle. Quelles responsabilités pour les sociétés transnationales? Le Monde, Paris, 8 Fev. 2015. Disponible à: <http://www.lemonde. $\mathrm{fr} /$ planete/visuel/2015/01/24/ecocide-episode-1-le-bois-quisaigne_4527270_3244.html\#sDDxAh2Sz0KV7qjS.99>. Accès: 2 Fev. 2016.

21 Cf. MARTIN-CHENUT, Kathia; PERRUSO, Camila. L'affaire Chevron Texaco et l'apport des projets de convention écocrimes et écocide à la responsabilisation pénales des entreprises transnationales. In: NEYRET, Laurent (Dir.). Des écocrimes à l'écocide: le droit pénal au secours de l'environnement. Bruxelles: Bruylant, 2015. p. 67-86.

22 Cf. TRICOT, Juliette. Ecocrimes et écocide: quels responsa- 
Assim, a parte a necessidade de estabelecer normas gerais em direito internacional público enquadrando a criminalidade ambiental, regras internacionais de articulação de competências em matéria ambiental também são imperativas. Os pontos fracos da proteção do meio ambiente pelo direito penal são variadas: o caráter acessório das infrações em relação às regras administrativas muitas vezes variam de um Estado a outro, desvinculando-a de um valor social; a falta de legibilidade das infrações que são normalmente subordinadas a normas técnicas; a falta de coerência da noção de crime ambiental nos direitos internos e entre os Estados; a falta de vontade política ou de capacidade dos países em desenvolvimento para coibir tal crime em razão de seus aspectos lucrativos; ou a insuficiência dos meios utilizados pelos Estados desenvolvidos para combater a criminalidade ambiental, notadamente aquela praticada por suas empresas nacionais.

Nessa perspectiva, os danos causados ao meio ambiente, em virtude da criminalidade ambiental, afetam a biodiversidade e geram consequências catastróficas para o equilíbrio dos ecossistemas e do planeta, assim como à vida humana. A ausência de tratamento global à ecocriminalidade deixa um campo livre para um tratamento diferenciado de luta contra as infrações ambientais. Consequentemente, um regime jurídico coerente a ser estabelecido pelo direito internacional se impõe.

\section{A POTENCIALIDADE FUTURA DO DIREITO INTER- NACIONAL RELATIVA À CRIMINALIDADE AMBIENTAL}

O direito internacional deve apropriar-se da questão da criminalidade ambiental e instaurar um regime jurídico comum para a proteção ambiental. Ele deve ser racional, eficaz e legítimo, construído a partir de critérios determinados, tais quais a importância do valor protegido, a gravidade do dano, a ilicitude do comportamento do autor da infracção e da gravidade da sua culpa ${ }^{23}$. A racionalização da proteção penal do meio ambiente favorece desse modo dois movimentos de politica criminal: a simplificação do direito penal

bles?. In: NEYRET, Laurent (Dir.). Des écocrimes à l'écocide: le droit pénal au secours de l'environnement. Bruxelles: Bruylant, 2015. p. 141-164.

23 Cf. Ambrosio, Luca. Vers un droit pénal commun de l'environnement: critères et techniques d'incrimination. In: NEYRET, Laurent (Dir.). Des écocrimes à l'écocide: le droit pénal au secours de l'environnement. Bruxelles: Bruylant, 2015. p. 88-107. do meio ambiente e a internacionalização da proteção do meio ambiente pelo direito penal ${ }^{24}$ (3.1). Esse regime jurídico facilitaria o estabelecimento de um sistema coerente com vistas a prevenir e a reprimir, se necessário, a criminalidade ambiental (3.2).

\subsection{O estabelecimento de uma penalização comum, gradual e racional aos danos ao meio ambiente: dos ecocrimes ao ecocídio}

A criminalidade ambiental é um dos grandes desafios da comunidade internacional, haja vista a proteção do meio ambiente ser um dos principais imperativos da atualidade. Para tratar da ecocriminalidade, a determinação de uma graduação entre os tipos de crimes é fundamental. Assim, o reconhecimento de crimes comuns que devem ser melhor enquadrados por uma matriz internacional comum e de crimes ambientais graves e excepcionais que merecem uma resposta penal específica clarificariam a constituição de um sistema penal justo relativo ao meio ambiente.

A partir da análise dos textos relativos aos direitos nacionais e internacionais assim como da jurisprudência de ambos os níveis, verifica-se que seria possível classificar, hierarquicamente, dois tipos de valores protegidos que justificariam as incriminações penais ambientais: o respeito das regras administrativas e de valores respectivos e o respeito de um valor superior ligado à segurança do planeta. A adoção desses instrumentos permitiria estabelecer uma coerência da tipificação dos crimes ambientais que é atualmente esparsa, a fim de solucionar as disparidades entre os instrumentos variados de direito internacional. Vale ressaltar que a harmonização não se traduz em unificação ou uniformização; ela prevê uma aproximação em torno de princípios comuns ${ }^{25}$.

As proposições de convenção ecocrimes e ecocídio preconizam uma classificação dos crimes ambientais em nível internacional distinguindo as infrações administrativas, os ecocrimes e o ecocídio e, consequentemente,

24 FOUCHARD, Isabelle; NEYRET, Laurent. 35 propositions pour mieux sanctionner les crimes contre l'environnement. In: NEYRET, Laurent (Dir.). Des écocrimes à l'écocide: le droit pénal au secours de l'environnement. Bruxelles: Bruylant, 2015. p. 305-442. BEAUVAIS, Pascal. Les limites de l'internationalisation du droit pénal de l'environnement. In: NEYRET, Laurent (Dir.). Des écocrimes à l'écocide: le droit pénal au secours de l'environnement. Bruxelles: Bruylant, 2015. p. 3-18.

25 DELMAS-MARTY, Mireille. Préface. In: NEYRET, Laurent (Dir.). Des écocrimes à l'écocide: le droit pénal au secours de l'environnement. Bruxelles: Bruylant, 2015. p. vii-xiii. p. xi. 
buscam contribuir à descriminalização de condutas cujo valor não justificaria uma proteção penal. Assim, a fim de lutar contra o fórum shopping dos autores de atos de degradação ambiental, essa harmonização internacional de proteção penal do meio ambiente é necessária.

Os ecocrimes ${ }^{26}$ apresentam-se sob diversas formas e a determinação em um único instrumento agrupando os comportamentos aos quais deveriam corresponder respostas penais justifica-se em razão da sua contribuição ao reforço à proteção do meio ambiente do qual depende a integridade humana. Por sua vez, o ecocídio ${ }^{27}$, cometido deliberadamente como parte de uma ação generalizada ou sistemática e que pode comprometer a segurança do planeta, exige uma ação conjunta entre os Estados, razão pela qual um instrumento internacional deveria ser adotado para erigi-lo no âmbito dos crimes mais graves contra o meio ambiente.

Esse processo de internacionalização da proteção ambiental pelo direito penal encorajaria a simplificação dos direitos nacionais, por meio da descriminalização dos atos que não justificariam sua legitimidade penal, favorecendo uma melhor articulação entre as sanções civis, administrativas e penais. Ademais, ele teria por função harmonizar o direito penal relativo aos ecocrimes em nível internacional. Essa iniciativa permitiria que a margem discricionária dos Estados fosse reduzida no que se refere à persecução da criminalidade ambiental transnacional. Nesse ensejo, a adoção de mecanismos capazes de assegurar a cooperação internacional para lutar contra a grave criminalidade ambiental, por meio de órgãos internacionais independentes previstos pelo projeto de convenção internacional relativo ao ecocídio, como pela figura de um procurador internacional ${ }^{28} \mathrm{e}$ de um grupo de pesquisa e de investigação sobre o meio ambiente (GREEN) ${ }^{29}$, reforçariam esse aspecto de cooperação internacional.

Um fator essencial relativo à adoção de um instrumento internacional relativo ao ecocídio seria a possibilidade de unificar a sanção de tal crime internacional. $O$ movimento de internacionalização de um direito penal ambiental se inscreveria, enfim, na tendência atual e urgente de proteção desse bem jurídico não somente em razão de seu valor intrínseco ${ }^{30}$, mas especialmente por-

26 Cf. Projeto de Convenção contra a criminalidade ambiental. Anexo.1

27 Cf. Projeto de Convenção contra o ecocídio. Anexo 2.

28 Cf. artigo 17 do projeto de Convenção ecocídio.

29 Cf. artigo 20 do projeto de Convenção ecocídio.

30 Cf. HELLIO, Hugues. De la valeur partagée de la sûreté de que dele depende a segurança do planeta e da proteção dos direitos humanos como um todo ${ }^{31}$.

\subsection{A imperatividade da prevenção e da re- pressão da criminalidade ambiental em direito internacional}

É inegável que a proteção do meio ambiente depende da ação humana. O homem é o responsável por sua salvaguarda e, por essa razão, tem obrigações em relação a ele. Nesse sentido, não é possível fundá-la somente no princípio de não regressão adotado durante a Conferência de Rio +20 , pois as categorias jurídicas devem ser revistas à luz das práticas fatuais. Assim, "somente conceitos inovadores, 'dos ecocrimes ao ecocídio', parecem capazes de criar uma dinâmica, de iniciar processos transformadores que permitirão ampliar a visão tradicional do direito penal identificado ao Estado e limitado à proteção de valores nacionais" 32 .

O processo de internacionalização da repressão penal objetiva estabelecer meios para melhorar a sanção dos crimes ambientais, seja pela adaptação da justiça punitiva, seja pela adoção de medidas de justiça restaurativa, que implicariam a adoção de linhas diretivas que guiariam a reparação do dano ecológico, tais quais a adoção de programas de conformidade, a reparação integral ou ainda a criação de um fundo para o meio ambiente.

Ademais, as proposições de projetos de convenção ecocrimes e ecocídio visam à inibição da prática do ato ilícito, pela antecipação da responsabilidade penal. Os agentes que estariam implicados em uma infração ambiental sopesariam suas ações. Esse aspecto preventivo da repressão penal visa evitar que as pessoas físicas ou

la planète à la répression internationale de l'écocide. Une nouvelle quête. In: NEYRET, Laurent (Dir.). Des écocrimes à l'écocide: le droit pénal au secours de l'environnement. Bruxelles: Bruylant, 2015. p. 109-126.

31 Cf. DELAGE, Geneviève Giudicelli; MARTIN-CHENUT, Kathia. Humanisme et protection de la nature. In: BRÉCHIGNAC, Catherine; BROGLIE, Gabriel de; DELMAS-MARTY, Mireille (Dir.). L'environnement et ses métamorphoses. Paris: Hermann, 2015. p. 231-246; MARTIN-CHENUT, Kathia; PERRUSO, Camila. La contribution des systèmes régionaux de protection des droits de l'homme à la pénalisation des atteintes à l'environnement. In: NEYRET, Laurent (Dir.). Des écocrimes à l'écocide: le droit pénal au secours de l'environnement. Bruxelles: Bruylant, 2015. p. 39-66. 32 DELMAS-MARTY, Mireille. Préface. In: NEYRET, Laurent (Dir.). Des écocrimes à l'écocide: le droit pénal au secours de l'environnement. Bruxelles: Bruylant, 2015. p. vii-xiii. p. viii. 
morais ajam com negligência e que elas adotem uma abordagem positiva de proteção ambiental. Ademais, os projetos de convenção preveem métodos que objetivam melhorar a promoção de boas práticas assim como a formação de profissionais implicados na luta contra a ecocriminalidade.

\section{Considerações finais}

A possibilidade de apreensão da questão da criminalidade ambiental pelo direito internacional na sua vertente penal pode despertar a crítica de alguns e o ceticismo de outros. Se a crítica refere-se, sobretudo, aos importantes debates quanto a não legitimidade do direito penal como solução mágica a todos os problemas sociais, a pretensão de erigir a proteção do meio ambiente como um valor superior justificando sua tutela por meio do direito penal provoca um generalizado ceticismo.

Ora, neste trabalho de pesquisa apresentado, ao movimento de penalização da criminalidade ambiental, corresponde um movimento de descriminalização. Não se trata portanto de proposta tendente a favorecer uma hipertrofia penal. O que se busca alcançar é sobretudo uma racionalização do direito penal, que se faz necessária por meio da repressão de condutas que vão ao encontro da proteção de valores superiores. A obrigação de incriminação de certos comportamentos tidos como graves, assim como de sua persecução penal e de sanção correspondente, faz parte de um sistema democrático, visto que essa necessidade é a contrapartida natural do princípio de intervenção penal mínima. Nessa direção, o princípio de subsidiariedade que guia esse ramo do direito é garantido pelas proposições de projetos de convenção anexas ao presente artigo. Elas não somente estabelecem uma distinção entre os ecocrimes e o ecocídio, como propõem uma gradação das medidas repressivas em função da gravidade da infração. Ademais, essa perspectiva de racionalização do direito penal tem como consequência a descriminalização das infrações mais leves ${ }^{33}$.

Finalmente, imaginar uma renovação da ordem jurídica internacional, que funda, ao lado do respeito dos direitos humanos, a proteção do meio ambiente ${ }^{34}$, cons-

33 MARTIN-CHENUT, Kathia; PERRUSO, Camila. La contribution des systèmes régionaux de protection des droits de l'homme à la pénalisation des atteintes à l'environnement. In: NEYRET, Laurent (Dir.). Des écocrimes à l'écocide: le droit pénal au secours de l'environnement. Bruxelles: Bruylant, 2015. p. 39-66. p. 64-65.

34 BELAIDI, Nadia. La lutte contre les atteintes globales à l'environnement: titui uma tendência absolutamente legítima e que se inscreve em um processo de evolução dos valores comuns compartilhados pela humanidade. Nesse sentido, face a forças dogmáticas que resistiriam à possibilidade de constituição de um sistema visando à proteção penal do meio ambiente em direito internacional, cumpre relembrar que "todo grande movimento deve passar pela experiência de três etapas: o ridículo, a discussão e a adoção" 35 .

\section{REFERÊNCIAS}

AMBROSIO, Luca. Vers un droit pénal commun de l'environnement: critères et techniques d'incrimination. In: NEYRET, Laurent (Dir.). Des écocrimes à l'écocide: le droit pénal au secours de l'environnement. Bruxelles: Bruylant, 2015. p. 88-107.

AMNESTY INTERNATIONAL. Côte d'Tvoire une vérité toxique. à propos de trafigura, du probo koala et du déversement de déchets toxiques en Côte d'Ivoire. 25 Sep. 2012. Disponible dans: <http://www.amnesty.org/fr/documents/ AFR31/002/2012/fr/>. Accès: 02 Fev. 2016.

BEAUVAIS, Pascal. Les limites de l'internationalisation du droit pénal de l'environnement. In: NEYRET, Laurent (Dir.). Des écocrimes à l'écocide: le droit pénal au secours de l'environnement. Bruxelles: Bruylant, 2015. p. 3-18.

BELAIDI, Nadia. La lutte contre les atteintes globales à l'environnement: vers un ordre public écologique. Bruxelles: Bruylant, 2008.

CONVENÇÃO de Basileia e controle de movimentos transfronteiriços de resíduos perigosos e sua eliminação. 1989. Disponível em: <http://www.ecomodus. eu/downloads/Basel_Convention-pt.pdf $>$. Acesso em: 01 fev. 2016.

CONVENÇÃO Internacional para a Prevenção da Poluição por Navios (MARPOL 73/78). 1973. Disponível em: <http://www.fd.unl.pt/docentes_docs/ma/jc_ MA_26322.pdf>. Acesso em: 01 fev. 2016.

CONVENÇÃO Sobre o Comércio Internacional das

vers un ordre public écologique. Bruxelles: Bruylant, 2008.

35 Segundo a fórmula de J. S. Mill na obra de Tom Regan "o direito dos animais". Cf MARGUENAUD, Jean-Pierre. Une révolution théorique: l'extraction masquée des animaux de la catégorie des biens. JCP G, Paris, n. 10-11, p. 495-501, 9 Mars 2015. p. 500. 
Espécies Selvagens da Fauna e da Flora Ameaçadas de Extinção. 1973. Disponível em: <http://eur-lex.europa.eu/legal-content/PT/TXT/PDF/?uri=CELEX:2 2015A0319(01)\&from=PT> . Acesso em: 01 fev. 2016

DELAGE, Geneviève Giudicelli; MARTIN-CHENUT, Kathia. Humanisme et protection de la nature. In: BRÉCHIGNAC, Catherine; BROGLIE, Gabriel de; DELMAS-MARTY, Mireille (Dir.). L'environnement et ses métamorphoses. Paris: Hermann, 2015. p. 231-246.

DELMAS-MARTY, Mireille. Perspectives ouvertes par le droit de l'environnement. Revue Juridique L'Environnement, Paris, v. 39, p. 7-13, 2014. Numéro spécial: Le droit répressif: quelles perspectives pour le droit de l'environnement.

DELMAS-MARTY, Mireille. Préface. In: NEYRET, Laurent (Dir.). Des écocrimes à l'écocide: le droit pénal au secours de l'environnement. Bruxelles: Bruylant, 2015. p. vii-xiii.

ESTUPIÑAN-SILVA, Rosmerlin. La lutte contre la criminalité environnementale au sein des Etats. In: NEYRET, Laurent (Dir.). Des écocrimes à l'écocide: le droit pénal au secours de l'environnement. Bruxelles: Bruylant, 2015. p. 19-38.

EUROPEAN UNION'S JUDICIAL COOPERATION UNIT. Strategic Project on Environmental Crime: report. Haag: Eurojust, Nov. 2014. Available in: $<$ http://www.eurojust.europa.eu/doclibrary/eurojustframework/casework/strategic $\% 20$ project $\% 20$ on $\% 20$ environmental $\% 20$ crime $\% 20$ (october $\% 202014$ )/environmental-crime-report_2014-11-21-en.pdf $>$. Access: Feb. 02, 2016.

FALK, Richard. Environment warfare and ecocide: facts, appraisal and proposals. Révue Belge de Droit International, Brussels, n. 11, p. 1-27, 1973.

FOUCHARD, Isabelle; NEYRET, Laurent. 35 propositions pour mieux sanctionner les crimes contre l'environnement. In: NEYRET, Laurent (Dir.). Des écocrimes à l'écocide: le droit pénal au secours de l'environnement. Bruxelles: Bruylant, 2015. p. 305-442.

HELLIO, Hugues. De la valeur partagée de la sûreté de la planète à la répression internationale de l'écocide: une nouvelle quête. In: NEYRET, Laurent (Dir.). Des écocrimes à l'écocide: le droit pénal au secours de l'environnement. Bruxelles: Bruylant, 2015. p. 109-126.

LE MONDE. Les Prédateurs, la nature face au crime organisé.
Paris: Ateliers Henry Dougier, 2015.

MARGUENAUD, Jean-Pierre. Une révolution théorique: l'extraction masquée des animaux de la catégorie des biens. JCP G, Paris, n. 10-11, p. 495-501, 9 Mars 2015.

MARTIN-CHENUT, Kathia; FOUCHARD, Isabelle. Quelles responsabilités pour les sociétés transnationales? Le Monde, Paris, 8 Fev. 2015. Disponible à: <http:/ / www.lemonde.fr/planete/visuel/2015/01/24/ecocide-episode-1-le-bois-qui-saigne_4527270_3244. html\#sDDxAh2Sz0KV7qjS.99>. Accès: 2 Fev. 2015.

MARTIN-CHENUT, Kathia; PERRUSO, Camila. L'affaire Chevron Texaco et l'apport des projets de convention écocrimes et écocide à la responsabilisation pénales des entreprises transnationales. In: NEYRET, Laurent (Dir.). Des écocrimes à l'écocide: le droit pénal au secours de l'environnement. Bruxelles: Bruylant, 2015. p. 67-86.

MARTIN-CHENUT, Kathia; PERRUSO, Camila. La contribution des systèmes régionaux de protection des droits de l'homme à la pénalisation des atteintes à l'environnement. In: NEYRET, Laurent (Dir.). Des écocrimes à l'écocide: le droit pénal au secours de l'environnement. Bruxelles: Bruylant, 2015. p. 39-66.

MOZAMBIQUE: le trafic à grande échelle d'ivoire et de cornes de rhinocéros continue. Le Monde, Paris, 14 Mai. 2014. Disponible à: <http://www.lemonde.fr/ afrique/article/2015/05/14/mozambique-le-trafic-agrande-echelle-d-ivoire-et-de-cornes-de-rhinoceroscontinue_4633777_3212.html>. Accès: 2 Fev. 2016.

NAÇÕES UNIDAS. Tribunal Penal Internacional. Estatuto de Roma. Disponível em: <http://www.un.org/ spanish/law/icc/statute/spanish/rome_statute(s). pdf>. Acesso em: 01 fev. 2016.

NEYRET, Laurent. Des écocrimes à l'écocide, un groupe de juristes au secours de l'environnement. In: In: BRÉCHIGNAC, Catherine; BROGLIE, Gabriel de; DELMAS-MARTY, Mireille (Dir.). L'environnement et ses métamorphoses. Paris: Hermann, 2015. p. 183-193.

NEYRET, Laurent. La criminalité environnementale c'est gros profits pour petits risques. Disponible dans: <http://www.europe1.fr/emissions/europe-1-vousrepond/neyret-la-criminalite-environnementale-cestgros-profits-pour-petits-risques-2617361>. Accès: 02 Fev. 2016.

NEYRET, Laurent. Pour la reconnaissance du crime d'écocide, 
Paris, v. 39, p. 179-194, 2014. Numéro spécial: Le droit répressif: quelles perspectives pour le droit de l'environnement.

QUEINNEC, Yann. L'affaire Probo Koala, symbole d'une responsabilité sociétale des entreprises en quête de sécurité juridique. In: GUIDICELLI-DELAGE, Geneviève; S. MANACORDA, Stefano (Dir.). La responsabilité pénale des personnes morales: perspectives européennes et internationales. Paris: Société de législation comparée, 2013. (Unité mixte de recherche de droit comparé de Paris; v. 30). p. 277-293.

TRICOT, Juliette. Ecocrimes et écocide: quels responsables?. In: NEYRET, Laurent (Dir.). Des écocrimes à l'écocide: le droit pénal au secours de l'environnement. Bruxelles: Bruylant, 2015. p. 141-164.

\section{Anexo 1}

\section{Projeto de Convenção contra a criminalidade ambiental (Convenção Ecocrimes)}

\section{Preâmbulo}

Os Estados Partes,

Conscientes que a preservação do meio ambiente natural condiciona o futuro da humanidade,

Preocupados pela progressão das infrações contra o meio ambiente e por seus efeitos, que se estendem cada vez mais além das fronteiras dos Estados onde essas infrações são cometidas,

Preocupados pelas estreitas e crescentes relações entre a criminalidade ambiental e as outras formas de criminalidade internacional, tais quais a criminalidade transnacional organizada, os tráficos ilícitos, a lavagem de dinheiro ou ainda a corrupção e em plena conformidade com os textos já adotados relativos à matéria pela Organização das Nações Unidas, conscientes que a criminalidade ambiental tem um impacto não somente sobre o meio ambiente, mas igualmente sobre a paz, a segurança e as economias nacionais, assim como incidências nefastas sobre os planos sanitário e social, suscetíveis de comprometer o desenvolvimento sustentável,

Determinados a responder, de maneira eficaz e adaptada, a essa criminalidade que necessita uma abordagem global e multidisciplinar para preservar o meio ambiente e a saúde humana,

Conscientes que as disparidades entre as legislações e as capacidades nacionais favorecem a criminalidade ambiental e necessitando que uma importante cooperação internacional, tendo em conta as responsabilidades comuns mas diferenciadas dos Estados,

Notando que um certo número de acordos internacionais e regionais tratam da questão da proteção e da preservação do meio ambiente, mas que os sistemas de sanção existentes não são suficientes a garantir o respeito efetivo da legislação em matéria de proteção do meio ambiente,

Conscientes que esse respeito pode e deve ser reforçado pela existência de sanções penais, que refletem uma desaprovação da sociedade qualitativamente diferente daquela manifestada pelas sanções administrativas ou de indenização civil,

Notando, ademais, a existência de múltiplas convenções internacionais de cooperação penal, mas nenhuma que trate, especificamente, do meio ambiente e determinadas a reforçar o recurso ao direito penal, em suas diversas dimensões preventivas e repressivas, sem prejuízo de todos os outros meios disponíveis, civis e administrativos, a serviço notadamente da reparação dos danos ao meio ambiente e da indenização das vitimas,

Notando as iniciativas nessa direção de múltiplas organizações internacionais e notadamente do Programa das Nações Unidas para o meio ambiente, do Escritório das Nações Unidas contra a droga e o crime e da Interpol,

Afirmando que os Estados devem cumprir suas obrigações internacionais relativas à proteção e a salvaguarda do meio ambiente e são responsáveis a esse respeito em conformidade com o direito internacional,

Convencidos que as medidas eficazes, especialmente de natureza penal, devem ser tomadas com urgência para promover a cooperação, a fim de prevenir e de combater mais eficazmente a criminalidade ambiental:

Convém o seguinte: 


\section{Capítulo: Disposições gerais}

\section{Artigo 1 - Terminologia}

Para os fins da presente Convenção:

1. Por "ilícito" compreende-se:

a) todo comportamento contrário ao direito do Estado sobre o território no qual é cometido, caracterizado pela violação de uma lei, uma regra administrativa, ou uma decisão de uma autoridade competente, visando à proteção do meio ambiente;

b) O comportamento é igualmente considerado como ilícito:

i) quando os fatos foram cometidos por uma pessoa física ou jurídica estrangeira em um Estado no qual as disposições protetoras do meio ambiente estabelecem um nível de proteção manifestamente inferior ao nível estabelecido no Estado da nacionalidade da pessoa física ou naquela a pessoa jurídica tem sua sede ou ainda no Estado de onde provêm os rejeitos;

ii) quando os fatos foram cometidos com base em uma autorização ou de uma licença que foi obtida por meio da corrupção, do abuso de funções de um agente público ou por meio de ameaças, no sentido da Convenção das Nações Unidas contra a corrupção.

2. Por "ecossistemas", compreendem-se as dinâmicas complexas formadas de comunidades de plantas, de animais, de microrganismos e de se meio ambiente não vivo que, por sua interação, formam unidades funcionais.

3. Por "pessoa jurídica", compreende-se toda entidade, tendo a personalidade jurídica em virtude do direito aplicável, exceção feita aos Estados ou entidades públicas no exercício de suas prerrogativas de autoridade pública e de organizações internacionais públicas.

4. Por "pessoa jurídica estrangeira", compreende-se:

a) uma pessoa jurídica onde a sede situa-se em um Estado diferente daquele onde é realizado o comportamento proibido ou por uma de suas filiais, $\mathrm{ou}$

b) uma pessoa jurídica onde a sede é situada no
Estado onde é realizado o comportamento proibido, mas que realiza a atividade na ocasião em que se produz esse comportamento por intermédio de uma pessoa jurídica estrangeira ou de uma filial.

Para determinar a nacionalidade da pessoa jurídica, os Estados poderão levar em consideração o critério da sede, assim como do lugar onde a pessoa jurídica realiza sua atividade principal ou seu principal centro administrativo.

\section{Artigo 2 - Campo de aplicação}

1. A presente Convenção se aplica à prevenção e à repressão das infrações estabelecidas em conformidade com seus artigos 3 e 4, assim como à reparação de suas consequências.

2. A presente Convenção é sem prejuízo das normas aplicáveis ao crime de ecocídio e das normas aplicáveis às infrações às regras administrativas enquadrando a proteção do meio ambiente.

\section{Capítulo 2: Definições das infrações}

\section{Artigo 3 - dos prejuízos ao meio ambiente}

1. Cada EstadoParte adota as medidas legislativas e autras necessárias para conferir o caráter de infração penal o fato de 'colocar em perigo ${ }^{36}$ o meio ambiente que decorre de atos ilícitos, cometidos intencionalmente ou por negligência ao menos grave, como segue:

a) o rejeito, a emissão ou a introdução de uma quantidade de substâncias ou de radiações ionizantes no ar ou na atmosfera, nos solos, nas águas ou nos meios aquáticos;

b) a coleta, o transporte, a valorização ou a eliminação de lixo, inclusive a supervisão dessas operações assim como o entretenimento subsequente dos locais de descarga e notadamente as ações empreendidas como negociador ou corretor em toda atividade relacionada à gestão do lixo;

c) a exploração de uma usina naquela uma atividade perigosa é exercida ou substâncias ou preparações perigosas são estocadas ou utilizadas;

36 Em francês: mise en danger. 
d) a produção, o tratamento, a manipulação, a utilização, a detenção, a armazenagem, o transporte, a importação, a exportação ou a eliminação de matérias nucleares ou de outras substâncias radioativas perigosas;

e) a produção, a importação, a exportação, colocar à venda ou a utilização de substâncias enfraquecendo a camada de ozônio;

f) a morte, a destruição, a possessão ou a captura de espécimes de espécies selvagens da fauna e da flora salvo nos casos em que os atos portam sobre uma quantidade ínfima dessas espécimes e têm um impacto ínfimo sobre o estado de conservação da espécie;

g) o comércio de espécimes de espécies da fauna ou da flora selvagens ou de partes ou produtos delas advindos portam sobre uma quantidade ínfima dessas espécimes e têm um impacto ínfimo sobre o estado de conservação da espécie;

h) todo outro ato ilícito de caráter análogo suscetível de colocar em perigo o meio ambiente.

2. Ocorre o ato de 'colocar em perigo' o meio ambiente quando os atos enumerados no parágrafo precedente criam um risco de degradação substancial dos ecossistemas na sua composição, sua estrutura ou seu funcionamento.

3. É uma circunstância agravante o fato de causar uma degradação substancial dos ecossistemas em sua composição, sua estrutura ou seu funcionamento.

\section{Artigo 4 - das violações à pessoa}

Cada Estado-Parte adota as medidas legislativas e outras necessárias para conferir o caráter de infração penal ao fato de colocar em perigo uma outra pessoa que decorre dos atos cometidos intencionalmente ou por negligência ao menos grave, como segue:

a) o rejeito, a emissão ou a introdução de uma quantidade de substâncias ou de radiações ionizantes no ar ou na atmosfera, nos solos, nas águas ou nos meios aquáticos;

b) a coleta, o transporte, a valorização ou a eliminação de lixo, inclusive a supervisão dessas operações assim como o entretenimento subsequente dos locais de descarga e notadamente as ações empreen- didas como negociador ou corretor em toda atividade relacionada à gestão do lixo;

c) a exploração de uma usina naquela uma atividade perigosa é exercida ou substâncias ou preparações perigosas são estocadas ou utilizadas;

d) a produção, o tratamento, a manipulação, a utilização, a detenção, a armazenagem, o transporte, a importação, a exportação ou a eliminação de matérias nucleares ou de outras substâncias radioativas perigosas;

e) todo outro ato de caráter análogo que cria um risco de causar a morte ou de graves lesões às pessoas.

2. Há ato de colocar em perigo uma outra pessoa quando os atos enumerados no parágrafo precedente criam um risco de causar a morte ou graves lesões a pessoas.

3. É uma circunstância agravante o fato de causar a morte ou graves lesões a pessoas em consequência dos atos enumerados no parágrafo 1.

\section{Artigo 5 - participação às infrações}

No sentido da presente Convenção, comete uma infração penal quem:

a) Comete uma ou diversas infrações previstas nos artigos 3 e 4 da presente Convenção;

b) Organiza o cometimento de tal infração ou dá a ordem a outras pessoas de cometê-la;

c) Torna-se cúmplice de tal infração, inclusive fornindo os meios desse cometimento, notadamente pela fabricação de falsos documentos ou da falsificação de documentos;

d) Contribui de toda outra maneira ao cometimento de tal infração por um grupo de pessoas agindo em concerto. Esse concurso deve ser deliberado e, segundo o caso:

i) Visar facilitar a atividade criminal ou a arquitetura criminal do grupo, se essa atividade ou essa arquitetura comporta a execução de um crime previsto pela presente Convenção; ou

ii) Ser realizada em plena consciência da intenção do grupo de cometer esse crime. 


\section{Artigo 6 - Responsabilidade penal das pessoas morais}

1. Cada Estado-Parte, em conformidade com os seus princípios jurídicos, adota as medidas necessárias para garantir que uma pessoa jurídica possa ser responsabilizada pelas infrações estabelecidas na presente Convenção, quando cometidos em seu nome, por qualquer pessoa que exerce um poder de direção, agindo, individualmente, ou como membro de um órgão da pessoa jurídica, em virtude:

a) de um mandato da pessoa jurídica;

b) de uma autoridade para tomar decisões em nome da pessoa jurídica; ou

c) de uma autoridade para exercer um controle no seio da pessoa jurídica.

2. Cada Estado-Parte, em conformidade com os seus princípios jurídicos, adota as medidas necessárias para garantir que uma pessoa jurídica possa ser responsabilizada penalmente quando, em virtude da sua falta de vigilância ou de controle, ela tenha tornado possível a prática de uma infração estabelecida em conformidade com a presente Convenção.

3. Sob reserva dos princípios jurídicos do Estado-Parte, a responsabilidade das pessoas morais pode ser penal, civil ou administrativa.

4. A responsabilidade penal das pessoas jurídicas estabelecidas nos termos dos parágrafos 1 e 2 não prejudica a responsabilidade penal das pessoas físicas que participaram na acepção do artigo 5 , às infrações visadas pelos artigos 3 e 4 .

\section{Capítulo 3: Medidas repressivas Seção 1: Sanções}

\section{Artigo 7 - Sanções contra as pessoas físicas}

1. Os Estados-Partes adotam as medidas necessárias para punir, de maneira eficaz, proporcional e dissuasiva as pessoas físicas reconhecidamente culpadas das infrações previstas na presente Convenção e para garantir a reparação dos danos ambientais e a indenização das vítimas.

2. Os Estados-Partes fazem das infrações visadas pela presente Convenção passíveis de penas que levam em consideração sua extrema gravidade. Para a escolha e a determinação da gravidade da sanção, os Estados-Partes levam em consideração, especialmente, os seguintes critérios:

a) Os benefícios econômicos advindo da infração, incluindo neste caso as economias que puderam resultar da não adoção de medidas de proteção ambiental;

b) A posição hierárquica do autor da infração, o fato de que ele tenha cometido o crime no âmbito das atividades de uma pessoa jurídica ou o seu estatuto de funcionário público;

c) A pronta reparação dos danos e a indenização das vítimas;

d) O caráter organizado do crime.

3. A reparação de danos toma formas tais como:

a) Medidas de restauração ambiental,

b) Reparação por danos materiais e morais,

c) Programas de conformidade,

d) Provisionamento do Fundo para o meio ambiente,

e) Medidas de desenvolvimento local;

f) e, de acordo com as circunstâncias, medidas de reparação simbólica adaptadas à dimensão cultural do dano ambiental, que podem se expressar em pedidos de desculpas às comunidades locais.

\section{Artigo 8 - Sanções contra as pessoas jurídicas}

1. Os Estados-Partes adotam as medidas necessárias para sancionar, de maneira eficaz, proporcional e dissuasiva as pessoas jurídicas reconhecidamente culpadas de uma das infrações visadas pela presente Convenção e para garantir a reparação dos danos ambientais e a indenização das vítimas.

2. Os Estados-Partes adotam as medidas necessárias para punir, de maneira eficaz, proporcional e dissuasiva as pessoas morais reconhecidamente culpadas de uma das infrações visadas pela presente Convenção. Em particular, os Estados-partes consideram estabelecer as sanções seguintes:
a) Multas;
b) Proibições, notadamente: 
- A dissolução da pessoa jurídica;

- O encerramento temporário ou definitivo dos locais ou estabelecimentos da pessoa jurídica;

- A suspensão, temporária ou definitiva, do todo ou de parte da atividade da pessoa jurídica no exercício daquela foi cometida, favorizada ou dissimulada a infração;

- A retirada de licenças, autorizações ou concessões;

- A proibição de receber subsídios e financiamentos públicos e de contratar com a administração pública.

c) Publicação da condenação. Quando há uma pluralidade de vítimas não identificadas, a publicação deve garantir que elas estejam conscientes do seu direito à indemnização;

d) Nomeação de um mandatário de justiça, a fim de que a pessoa jurídica adote as medidas organizacionais de natureza a prevenir novos crimes contra o meio ambiente ou que ela ele execute com diligência as medidas de reparação ou indenização.

3. A reparação de danos assume, notadamente, a forma de:

a) Medidas de restauração ambiental;

b) Reparação por danos materiais e morais;

c) Programas de Compliance;

d) Provisionamento do Fundo para o Meio Ambiente;

e) Medidas de desenvolvimento local;

f) E, dependendo das circunstâncias, de medidas de reparação simbólica adaptadas à dimensão cultural de danos ambientais, que podem assumir a forma de um pedido de desculpas para as comunidades afetadas;

4. Os Estados membros adotam as medidas necessárias para impedir que as sanções ou as consequências danosas que delas decorrem possam ser garantidas.

\section{Artigo 9 - critérios de determinação da sanção das pessoas jurídicas}

1. Para a escolha e a determinação da sanção, con- vém priorizar a reparação do dano e a indenização das vítimas.

2. Nos casos em que a multa possa comprometer a solvência da pessoa jurídica, a segurança dos empregos ou a reparação dos danos, os Estados-Partes podem fornecer a possibilidade de parcelar o pagamento. Nesses casos e, em conformidade com o direito interno, eles poderão, também, dar prioridade para a reparação do dano pela pessoa jurídica autora da infração.

3. Os Estados-Partes levarão em conta os seguintes critérios para a escolha e a determinação da gravidade da sanção:

a) O lucro econômico da infração, incluindo neste caso as economias que resultaram da falta de adoção de medidas de proteção ambiental;

b) A ausência ou a insuficiência de medidas de controles internos que teriam permitido a prevenção da infração;

c) A reiteração de infrações contra o meio ambiente no âmbito da ou pela pessoa jurídica. Para este fim, serão consideradas as sanções impostas às pessoas jurídicas por outras autoridades;

d) A natureza organizada do crime;

e) A colaboração da pessoa jurídica no processo penal, em particular no estabelecimento da responsabilidade;

f) A reparação imediata dos danos e a assistência às vítimas;

g) A adoção imediata de medidas de controle interno para destinadas a prevenir infrações similares.

4. A dissolução da pessoa jurídica e o encerramento definitivo das suas instalações ou atividades só serão pronunciados se a pessoa jurídica tiver sido criada para cometer os fatos incriminados ou quando ela será considerada como parte de um grupo criminoso organizado, tal como definido no Convenção das Nações Unidas contra o Crime Organizado Transnacional.

\section{Artigo 10 - Suspensão da execução da sanção, provas e acordos processuais}

1. Os Estados-Partes poderão, em conformidade com os princípios fundamentais de seu direito interno, prever a possibilidade de não impor sanção, de não exe- 
cutar ou de não processar a pessoa jurídica, nos casos em que ela cumprir, corretamente, suas medidas internas de organização e de maneira voluntária e imediata:

a) Avisou as autoridades competentes do cometimento de uma das infrações definidas pela presente Convenção, cometidas por um de seus empregados ou dirigentes;

b) Reparou ou se esforçou para reparar os danos causados e, em partículas, aqueles sofridos pelas vítimas;

2. Nessas hipóteses, a decisão de não impor uma sanção, de não executar e de não processar a pessoa jurídica poderá ser subordinada à realização de certas condições, especialmente:

a) a designação de um auditor público encarregado de supervisionar a adoção de medidas de prevenção apropriadas pela entidade, assim que a reparação do dano causado ou de investigar sobre as causas estando na origem do cometimento de uma infração contra o meio ambiente;

b) O pagamento de um montante que compense o benefício que a entidade pôde obter em razão do cometimento da infração ou da falta de respeito da legislação ambiental.

\section{Artigo 11 - confisco e apreensão}

1. Os Estados Partes adotam, na medida do possível no quadro de seus sistemas jurídicos nacionais, as medidas necessárias para permitir o confisco:

a) Do produto do crime derivado de infrações previstas pela presente Convenção ou de bens cujo valor corresponda ao desse produto.

b) Dos bens, materiais ou outros instrumentos utilizados ou destinados a serem utilizados na prática das infrações previstas na presente Convenção.

2. Os Estados Partes preveem a possibilidade de apreender os produtos do crime advindo de infrações visadas pela presente Convenção. Os produtos também incluem as economias resultando da não adoção de medidas de proteção ambiental;

3. Os Estados Partes adotam as medidas necessárias para permitir a identificação, a localização, o congelamento ou a apreensão dos elementos mencionados no parágrafo 1 do presente artigo, a fim de um eventual confisco;

4. Se o produto do crime tiver sido transformado ou convertido, no todo ou em parte, em outros bens, eles estão sujeitos às medidas referidas neste artigo no lugar do produto mencionado;

5. Se o produto do crime tiver sido misturado com bens adquiridos legalmente, esses bens, sem prejuízo de todos os poderes de congelamento ou de apreensão, podem ser confiscados até ao valor estimado do produto com o qual tenha sido misturado;

6. As receitas ou outros benefícios obtidos com o produto do crime, os bens nos quais o produto tenha sido transformado ou convertido ou os bens com os quais tenha sido misturado podem, também, ser objeto das medidas referidas no presente artigo, da mesma maneira e na mesma medida que o produto do crime;

7. Para efeitos deste artigo e do artigo 17 da presente Convenção, cada Estado-Parte habilita seus tribunais ou outras autoridades competentes para ordenarem a produção ou a apreensão de documentos bancários, financeiros ou comerciais. Os Estados-Partes não podem invocar o sigilo bancário para recusar de dar cumprimento às disposições do presente parágrafo;

8. A interpretação das disposições do presente artigo não deve em nenhum caso violar os direitos de terceiros de boa-fé;

9. Nenhuma disposição do presente artigo viola o princípio segundo o qual as medidas que são visadas são definidas e executadas em conformidade com o direito interno de cada Estado parte e segundo as disposições desse direito.

\section{Seção 2: Cooperação em matéria repressiva}

\section{Artigo 12 - Competências nacionais}

1. Cada Estado-parte adota as medidas necessárias para estabelecer sua competência relativa às infrações visadas pela presente Convenção nos casos seguintes:

a) Quando os fatos tenham sido cometidos em todo o território sob a jurisdição desse Estado; ou

b) Quando o resultado da infração é realizado em todo o território sob a jurisdição desse Estado; ou

c) Quando da infração for cometida a bordo de 
um navio de seu pavilhão ou a bordo de uma aeronave matriculada no seu direito nacional no momento em que a infração é cometida; ou

d) Quando da infração for cometida por um dos seus nacionais; ou

e) Quando a infração for cometida por uma pessoa jurídica que tenha a sua sede ou o sua atividade principal ou seu principal centro administrativo no seu território; ou

f) Quando a infração for cometida contra um dos seus nacionais e que o Estado o considere apropriado.

2. Cada Estado-Parte adota, igualmente, as medidas que sejam necessárias para estabelecer sua competência nos casos em que o suposto autor de uma infração prevista pela presente Convenção encontra-se em seu território e que ele não o extradite, nos termos do artigo 15, para qualquer um dos Estados-partes que tenham estabelecido sua competência de acordo com o parágrafo 1 .

3. Quando mais de um Estado-parte declara-se competente em relação a uma infração prevista pela presente Convenção, os Estados-partes interessados se esforçam para coordenar suas ações de forma adequada, em especial no que diz respeito às condições de engajamento de persecução e de modalidades de assistência jurídica mútua.

4. Sem prejuízo das normas do direito internacional geral, a presente Convenção não exclui o exercício de qualquer competência penal estabelecida por um Estado-Parte, em conformidade com seu direito interno.

\section{Artigo 13 - Investigação e persecução penal}

1. Se considerar que as circunstâncias justificam, depois de analisar as informações de que dispõe, qualquer Estado-parte em cujo território se encontra uma pessoa suspeita de ter cometido uma infração prevista nos artigos 3 e 4, assegura a detenção dessa pessoa ou toma todas as outras medidas legais para garantir sua presença. Essa detenção e essas outras medidas devem estar em conformidade com a legislação desse Estado; elas podem ser mantidas somente durante o tempo que for necessário para permitir o estabelecimento de um processo penal ou de um processo de extradição.

2. Tal Estado procede, imediatamente, a uma investi- gação preliminar com vistas a estabelecer os fatos.

3. Qualquer pessoa detida em virtude do parágrafo 1 deste artigo poderá se comunicar, imediatamente, com o representante competente mais próximo do Estado da sua nacionalidade ou, se for um apátrida, com o representante da Estado em que resida habitualmente.

4. Quando um Estado detém uma pessoa em custódia nos termos das disposições deste artigo, ele notifica, imediatamente, a detenção e as circunstâncias que a justificam aos Estados referidos no parágrafo 1 do artigo 10. O Estado que procede à investigação preliminar prevista no parágrafo 2 do presente artigo deve comunicar, rapidamente, as suas conclusões aos citados Estados e indicará se pretende exercer sua competência.

\section{Artigo 14 - participação da sociedade civil}

Cada Estado-parte visa a favorizar, em conformidade com seu direito interno, a informação da sociedade civil e sua participação aos processos penais relativos às infrações previstas pela presente Convenção, de um grupo, de uma fundação ou uma associação que, de acordo com seu estatuto, tem por objetivo a proteção do meio ambiente.

\section{Artigo 15 - extraditar ou processar}

1. O Estado-parte sobre o território e sob a jurisdição em que se encontra o presumível autor de uma infração prevista nos artigos 3 e 4, se não o extraditar, submete o caso às suas autoridades competentes para o exercício da ação penal.

2. Essas autoridades tomarão sua decisão nas mesmas condições que para qualquer outra infração de direito comum de natureza grave nos termos do direito desse Estado.

3. Toda pessoa processada por qualquer infração prevista nos artigos 3 e 4 beneficia da garantia de um tratamento equitativo em todas as fases do processo.

\section{Artigo 16 - extradição}

1. As infrações previstas nos artigos 3 e 4 são consideradas como passíveis de extradição em qualquer tratado de extradição concluído entre os Estados-partes antes da entrada em vigor da presente Convenção. Os 
Estados-partes comprometem-se a incluir essa infração como caso de extradição em todo tratado de extradição futuramente concluído.

2. Um Estado-parte que condiciona a extradição à existência de um tratado tem a faculdade, quando receber um pedido de extradição de outro Estado-parte com o qual não está vinculado por um tratado de extradição, de considerar essa Convenção como a base jurídica para a extradição relativamente às infrações previstas nos artigos 3 e 4. A extradição é sujeita às demais condições previstas pela legislação do Estado requerido.

3. Os Estados-partes que não condicionam a extradição à existência de um tratado reconhecendo as infrações previstas nos artigos 3 e 4 como caso de extradição entre eles, sem prejuízo das condições previstas pela legislação do Estado requerido.

4. Se necessário, as infrações previstas nos artigos 3 e 4 são consideradas, para efeitos de extradição entre os Estados Partes, como cometidas tanto no lugar de sua perpetração que no território dos Estados que estabeleceram sua competência de acordo com o artigo 12 .

5. As disposições relativas às infrações previstas nos artigos 3 e 4 de todos os tratados ou acordos de extradição concluídos entre Estados-Partes devem ser modificados entre Estados-Partes na medida em que elas são incompatíveis com a presente Convenção.

5. Para fins de extradição ou assistência jurídica mútua entre os Estados-Partes, nenhuma infração prevista nos artigos 3 e 4 não pode ser considerada como uma infração política, como uma infração conexa à uma infração política ou como uma infração inspirada por motivos políticos. Por conseguinte, um pedido de extradição ou de assistência jurídica mútua com base em tal infração não poderá ser recusada pela simples razão de que se trata de uma infração política, uma infração conexa à uma infração política ou uma infração inspirada por motivos políticos.

\section{Artigo 17 - Assistência jurídica mútua}

1. Os Estados-Partes acordam, mutualmente, uma ampla assistência jurídica para as investigações, os processos e os procedimentos judiciais relativos às infrações previstas por esta Convenção.

2. A assistência jurídica mútua é baseada no princípio do reconhecimento mútuo das sentenças e decisões judiciais dos Estados-Partes.

3. A mais ampla assistência jurídica mútua possível é concedida, desde que as leis, tratados, acordos e arranjos pertinentes do Estado Parte requerido a permita, quando das investigações, processos e procedimentos judiciais relativos a infrações pelas quais uma pessoa jurídica possa ser passível de responsabilidade no Estado-Parte requerente, em conformidade com o artigo 6 da presente Convenção.

4. A assistência jurídica mútua é realizada, também, em processos por fatos puníveis nos termos do direito nacional do Estado Membro requerente ou do Estado Membro requerido, ou ambos, a titulo de violações das regras investigadas pelas autoridades administrativas, cuja decisão pode gerar um processo perante um tribunal competente, notadamente em matéria penal.

5. Os Estados-Partes poderão invocar a falta de dupla incriminação para recusar dar seguimento a um pedido de assistência nos termos do presente artigo. $\mathrm{O}$ Estado-Parte requerido poderá, contudo, quando considerar apropriado, prestar essa assistência, na medida em que ele decide, a seu critério, independentemente do fato que a conduta possa constituir ou não uma infração nos termos do direito nacional do Estado-parte requerido.

6. Cada Estado-Parte designa uma autoridade central que tem a responsabilidade e o poder de receber as demandas de assistência jurídica mútua e, seja executá-las, seja transmiti-las às autoridades competentes para execução. As autoridades centrais garantem a execução ou a transmissão rápida e em adequada forma das demandas recebidas.

7. As demandas são endereçadas por escrito ou, se possível, por todo outro meio que possa produzir um documento escrito, em uma língua aceitável para o Estado-Parte requerido, nas condições que permitem a esse Estado de estabelecer sua autenticidade. Em caso de urgência e se os Estados-Parte convêm, as demandas podem ser feitas oralmente, mas devem ser confirmadas sem prazo por escrito.

8. Toda demanda é executada em conformidade com o direito interno do Estado-Parte requerido e, na medida em que ela não contrarie o direito interno desse Estado e quando é possível, de acordo com os procedimentos especificados na demanda.

9. A assistência jurídica mútua pode ser refusada: 
a) Se a demanda não é feita em conformidade com as disposições do presente artigo;

b) Se o Estado-Parte requerido estima que a execução da demanda é suscetível de causar um prejuízo à sua soberania, à sua segurança, à sua ordem pública ou a outros interesses essenciais;

c) Caso o direito interno do Estado-Parte requerido proíba suas autoridades de tomar as medidas demandadas tratando-se de uma infração análoga tendo sido objeto de uma investigação, de um processo ou de um processo judiciário no quadro de sua própria competência;

d) Caso ele seria contrário ao sistema jurídico do Estado-Parte requerido relativamente à assistência jurídica mútua de aceitar a demanda.

10. Toda recusa de assistência jurídica mútua deve ser motivada. Antes de recusar um pedido de assistência ou adiar sua execução, nos termos do parágrafo 11, o Estado-Parte requerido deve estudar com o Estado-Parte requerente a possibilidade de conceder a assistência sob reserva das condições que ele considerar necessárias. Se o Estado-Parte requerente aceitar a assistência jurídica mútua sujeita a condições, ele deverá respeitá-las.

11. O Estado-Parte requerente deverá executar a demanda de assistência jurídica mútua o mais rapidamente possível e deverá levar em conta, na medida do possível, todos os prazos sugeridos pelo Estado Parte requerente e que estão motivados de preferência na demanda. A assistência pode ser adiada pelo Estado-Parte requerido pelo motivo que ela interfere em uma investigação em curso, uma ação judicial ou um processo judicial em curso.

\section{Capítulo 4: Medidas preventivas}

\section{Artigo 18 - Cooperação internacional em maté- ria de prevenção}

1. Os Estados-Partes cooperam para prevenir as infrações previstas na presente Convenção, adotando todas as medidas possíveis, especialmente, se necessário, adaptando sua legislação nacional, para evitar e impedir a preparação em seus respectivos territórios de infrações a serem cometidas no interior ou fora do seu território.
2. Os Estados-Partes cooperam também para a prevenção das infrações previstas na presente Convenção, por meio da troca de informações precisas e verificadas em conformidade com sua legislação interna e por meio da coordenação de medidas administrativas e de outras medidas tomadas.

3. Os Estados-Partes podem trocar informações pelo intermédio de instituições regionais e internacionais interessadas na luta contra a criminalidade ambiental, incluindo a Interpol, a Europol e o Escritório das Nações Unidas sobre drogas e crime.

4. Os Estados-Partes dispensam ou reforçam a formação adequada dos profissionais pertinentes que tratam de autores e suspeitos de terem cometido uma das infrações previstas na presente Convenção e de suas vítimas.

5. Os Estados-Partes se esforçam para sensibilizar o público quanto à existência, às causas e à gravidade da criminalidade ambiental e à ameaça que ela representa. Eles podem fazê-lo, se necessário, por intermédio dos meios de comunicação social e pela adoção de medidas destinadas a promover a participação do público nas atividades de prevenção e de repressão desse crime.

6. Os Estados-Partes informam o Secretário da presente Convenção o nome e o endereço da autoridade ou das autoridades que podem ajudar as outras Partes a desenvolver as medidas de prevenção das infrações previstas na presente Convenção.

7. Os Estados-Partes colaboram, conforme sua conveniência, entre eles e com as instituições regionais e internacionais competentes, para desenvolver e promover as medidas visadas pelo presente capítulo.

\section{Capítulo 5: aplicação da convenção}

\section{Artigo 19 - Proteção da soberania}

1. Os Estados-Partes cumprirão as obrigações decorrentes da presente Convenção em conformidade com os princípios de igualdade soberana e de integridade territorial dos Estados, assim como da não ingerência nos assuntos internos de outros Estados.

2. Nenhuma disposição da presente Convenção autoriza qualquer Estado-Parte a exercer, no território de outro Estado-Parte, uma competência ou funções, 
exclusivamente, reservadas às autoridades desse outro Estado-Parte por seu direito interno.

\section{Artigo 20 - Implementação da Convenção}

1. Cada Estado-Parte adota as medidas necessárias, incluindo legislativas e administrativas, de acordo com os princípios fundamentais de sua legislação interna, para garantir o cumprimento das suas obrigações em virtude da presente Convenção.

2. Cada Estado-Parte poderá adotar medidas mais estritas ou mais severas do que as previstas pela presente Convenção para prevenir e punir os crimes internacionais mais graves contra o meio ambiente.

3. As disposições da presente Convenção são aplicadas e interpretadas de acordo com as regras do direito internacional geral e os princípios do direito internacional do meio ambiente, notadamente o princípio de responsabilidades comuns, mas diferenciadas.

\section{Artigo 21 - Exame do cumprimento das disposi- ções}

1. A Assembleia dos Estados-Partes adota, por consenso, disposições de caráter não conflituoso, de natureza não judicial e consultiva para examinar o cumprimento das disposições da presente Convenção.

2. Essas disposições deverão permitir uma apropriada participação do público e prever a opção de se admitirem comunicações de membros do público sobre questões relacionadas à presente Convenção.

3. O procedimento adotado por consenso para o exame do cumprimento das disposições da presente Convenção aplica-se sem prejuízo do processo de resolução de litígios previstos no artigo 22. Sempre que possível, as Partes deverão utilizar procedimentos preliminares relativos ao cumprimento antes de recorrer a mecanismos de solução de disputas.

\section{Artigo 22 - Solução de controvérsias}

1. Se surgir uma controvérsia entre duas ou mais Partes quanto à interpretação ou a aplicação desta Convenção, elas devem se esforçar para resolvê-la pela via da negociação ou por qualquer outro meio de resolução de disputas que elas considerarem aceitável. Além disso, as Partes procuram a melhor solução para o estado do meio ambiente e o respeito de seus direitos, pela implementação anterior, e, na medida do que é apropriado, do procedimento de exame do respeito das disposições previsto no artigo 21.

2. Quando uma Parte assina, ratifica, aceita, aprova ou adere à presente Convenção, ou em qualquer momento posterior, ela pode declarar por escrito ao depositário que, no caso de disputas, não foram resolvidas em conformidade com o parágrafo 1 acima, ela aceita como obrigatório um dos dois ou ambos os meios de solução de controvérsias abaixo em suas relações com qualquer Parte que aceite a mesma obrigação:

a) A submissão da controvérsia à Corte Internacional de Justiça;

b) A submissão da controvérsia à arbitragem;

3. Se as Partes na controvérsia aceitarem os dois meios de solução de controvérsias referidos no parágrafo 2 acima, a controvérsia poderá ser submetida apenas à Corte Internacional de Justiça, a menos que elas acordem o contrário.

\section{Artigo 25 - Medidas cautelares}

1. Se uma corte, um tribunal ou um órgão responsável pelo exame do respeito da Convenção, regularmente invocado por uma controvérsia ou uma situação que considere, prima facie, que tem jurisdição sobre a controvérsia ou sobre a situação, em conformidade com a presente Convenção, esse tribunal ou esse órgão pode prescrever quaisquer medidas cautelares que considere apropriadas à circunstância a fim de evitar o grave prejuízo ambiente ou para preservar os direitos respectivos das Partes em litígio, aguardando a decisão final.

2. As medidas cautelares podem ser modificadas ou retiradas no momento em que as circunstâncias que as justificavam mudem ou deixem de existir.

3. Medidas cautelares podem ser prescritas, modificadas ou retiradas em virtude do presente artigo pela demanda de uma Parte à controvérsia ou de todo membro do público interessado e habilitado a apresentar comunicações. As medidas cautelares podem ser prescritas, modificadas ou retiradas somente depois que a possibilidade de ser ouvido tenha sido dada às Partes.

4. A corte, o tribunal ou o órgão responsável pelo 
cumprimento da Convenção notifica, imediatamente, as diferentes Partes à controvérsia de qualquer medida cautelar ou qualquer decisão de modificação ou de retirada e, se considerar apropriado, quaisquer outras pessoas que julgar interessada.

5. Enquanto aguarda a constituição de um tribunal arbitral para apreciar a controvérsia nos termos do artigo 22, qualquer órgão jurisdicional designado de comum acordo pelas Partes ou, na falta de acordo no prazo de duas semanas a contar da data do pedido de medidas cautelares, a Corte Internacional de Justiça pode prescrever, modificar ou revogar medidas cautelares em conformidade com o presente artigo, se considerar que, prima facie, o tribunal a ser constituído teria jurisdição e se ela estima que a urgência da situação exige. Uma vez constituído, o tribunal que julgará a controvérsia, de acordo com os parágrafos 1 a 4, pode modificar, revogar ou confirmar essas medidas cautelares.

6. As Partes à controvérsia se conformam sem demora a todas as medidas cautelares prescritas em virtude deste artigo.

\section{Capítulo 4: Disposições finais}

$\mathrm{Na}$ ausência de especificidade própria em matéria de infrações ambientais a esse respeito, as disposições finais não serão na presente objeto de desenvolvimentos.

\section{Anexo 2 \\ Projeto de Convenção contra o ecocídio (Convenção Ecocídıo)}

\section{Preâmbulo}

Os Estados-Partes à presente Convenção,

Conscientes que todos os povos são unidos por uma solidariedade de destino e que seu meio ambiente constitui um patrimônio comum das gerações presentes e futuras, cuja proteção condiciona a sobrevivência da humanidade;

Conscientes de que o futuro da humanidade e a viabilidade do planeta relevam da responsabilidade de toda a comunidade internacional;
Preocupados com a expansão de crimes intencionais em detrimento do meio ambiente e com as consequências graves e duradouras, às vezes irreversíveis, ao equilíbrio ecológico e à humanidade;

Conscientes que as disparidades entre as legislações e as capacidades nacionais favorecem a criminalidade ambiental em escala mundial;

Notando que diversos acordos internacionais e regionais tratam da questão da proteção do meio ambiente, mas que os sistemas de sanção existentes não são suficientes para preservar a segurança do planeta;

Preocupados com os laços estreitos e crescentes entre a criminalidade ambiental e outras formas de criminalidade internacional, como a criminalidade transnacional organizada, os tráficos ilícitos, a lavagem de dinheiro ou ainda a corrupção e em plena conformidade com as disposições já adotadas nessa área pelas Nações Unidas;

Reconhecendo que os crimes mais graves contra o meio ambiente ameaçam a paz mundial, a segurança da humanidade e a segurança do planeta;

Afirmando que os crimes mais graves que ameaçam a comunidade internacional não podem ficar impunes e que sua repressão deve ser efetivamente assegurada por medidas tomadas em nível nacional e pelo reforço da cooperação internacional;

Determinados a pôr fim à impunidade dos autores desses crimes, a contribuir com a sua prevenção e com a reparação de suas consequências;

Relembrando que é dever de cada Estado de submeter à sua jurisdição penal os responsáveis por crimes internacionais;

Determinados, para essas finalidades e no interesse da segurança do planeta, a reforçar as condições de cooperação penal entre os Estados e que os crimes internacionais mais graves contra o meio ambiente, características do crime ecocídio, sejam objeto de sanções penais apropriadas;

Acordam o seguinte:

\section{Artigo 1- Campo de aplicação}

1. A presente Convenção aplica-se aos mais graves crimes contra o meio ambiente que, em tempos de paz como em tempo de conflito armado, prejudicam a segurança do planeta. 
2. A presente Convenção não se sobrepõe aos instrumentos pertinentes do Direito Internacional Humanitário que regulam os danos ambientais durante conflito armado.

\section{Capítulo 1: Medidas repressivas}

\section{Artigo 2: Definição do ecocídio}

1. Para os fins da presente Convenção, o ecocídio define-se como os atos intencionais descritos a seguir, quando eles comprometem a segurança do planeta e são cometidos no âmbito de uma ação generalizada ou sistemática:

a) O rejeito, a emissão ou a introdução de uma quantidade de substâncias ou de radiações ionizantes no ar ou na atmosfera, nos solos, nas águas e nos ambientes aquáticos;

b) A coleta, o transporte, a valorização ou a eliminação de resíduos, incluindo a fiscalização dessas operações e a posterior manutenção dos aterros e notadamente as medidas tomadas na qualidade de negociador ou corretor em qualquer atividade relacionada à gestão de resíduos;

c) A exploração de uma fábrica em que uma atividade perigosa é realizada ou substâncias ou preparações perigosas sejam armazenadas ou utilizadas;

d) A produção, o tratamento, a manipulação, a utilização, a detenção, a armazenagem, o transporte, a importação, a exportação ou a eliminação de materiais nucleares ou outras substâncias radioativas perigosas;

e) a morte, a destruição, a posse ou a captura de espécimes da fauna e da flora selvagens protegidos ou não;

f) outros atos de caráter análogo cometidos intencionalmente e que colocam em perigo a segurança do planeta.

2. Os atos referidos no parágrafo 1 afetam a segurança do planeta quando eles causam:

a) a degradação extensa, durável e grave do ar ou da atmosfera, dos solos, das águas, dos meios aquáticos, da fauna ou da flora, ou de suas funções ecológicas; ou b) a morte, a invalidez permanente ou doenças incuráveis graves a uma população, ou a desapropriação permanente dessa última de suas terras, territórios ou recursos.

3. Os atos referidos no parágrafo 1 devem ser cometidos intencionalmente e com conhecimento do caráter generalizado ou sistemático da ação em que se inserem. Esses atos são considerados como intencional quando seu autor sabia ou deveria saber que havia uma alta probabilidade de que eles afetam a segurança do planeta.

\section{Artigo 3: Participação ao crime de ecocídio}

Cada Estado-Parte adotará as medidas legislativas e outras necessárias, a fim de responsabilizar por um crime de ecocídio toda pessoa que, intencionalmente:

a) comete um tal crime, individualmente, em conjunto com uma outra pessoa, ou por intermédio de uma outra pessoa e que esta última seja ou não penalmente responsável;

b) dá a ordem, solicita ou instiga à comissão de tal crime, uma vez que haja cometimento ou tentativa de cometer esse crime;

c) com vistas a facilitar o cometimento de um tal crime, oferece sua ajuda, seu concurso ou toda outra forma de assistência para o cometimento ou a tentativa de comissão desse crime, inclusive pelo fornecimento de meios para sua comissão, particularmente pela fabricação de falsos documentos ou pela falsificação de documentos;

d) contribui de toda outra maneira para a prática ou tentativa de prática desse crime por um grupo de pessoas agindo em conjunto. Esta contribuição dever, de acordo com o caso:

i) visar a facilitar a atividade criminosa ou o propósito criminoso do grupo, quando tal atividade ou propósito envolver o cometimento de um crime de ecocídio; ou

ii) ser realizada com o conhecimento da intenção do grupo de cometer o crime;

e) tenta cometer tal crime por meio de atos que, por seu caráter substancial, constituem o começo da execução, mas sem que o crime ocorra em razão de circunstâncias independentes da sua vontade. 


\section{Artigo 4 - Imprescritibilidade}

O crime de ecocídio é imprescritível.

\section{Artigo 5 - Responsabilidade penal das pessoas morais}

1. Cada Estado-Parte, em conformidade com os seus princípios jurídicos, adota as medidas necessárias para garantir que uma pessoa jurídica possa ser responsabilizada, penalmente, por crime de ecocídio, quando cometidos em seu nome, por qualquer pessoa que exerce um poder de direção, agindo, individualmente, ou como membro de um órgão da pessoa jurídica, em virtude:

a) de um mandato da pessoa jurídica;

b) de uma autoridade para tomar decisões em nome da pessoa jurídica; ou

c) de uma autoridade para exercer um controle no seio da pessoa jurídica.

2. Cada Estado-Parte, em conformidade com os seus princípios jurídicos, adota as medidas necessárias para garantir que uma pessoa jurídica possa ser responsabilizada penalmente quando, em virtude da sua falta de vigilância ou de controle, ela tenha tornado possível a prática de um crime de ecocídio em seu nome.

3. A responsabilidade penal das pessoas jurídicas estabelecidas nos termos dos parágrafos 1 e 2 não prejudica a responsabilidade penal das pessoas físicas que participaram na acepção do artigo $3 \mathrm{em}$ um crime de ecocídio.

4. Por "pessoa jurídica", entende-se qualquer entidade dotada de personalidade jurídica nos termos da legislação aplicável, com exceção do Estado ou de entidades públicas no exercício de suas prerrogativas de autoridade pública e das organizações internacionais públicas.

\section{Artigo 6 - Sanções contra as pessoas físicas}

1. Os Estados-Partes adotam as medidas necessárias para sancionar, de maneira eficaz, proporcional e dissuasiva as pessoas físicas reconhecidamente culpadas do crime de ecocídio e para garantir a reparação dos danos ambientais e a indenização das vítimas.

2. Os Estados-Partes fazem do ecocídio um crime passível de sanções que levam em consideração sua ex- trema gravidade. Essas sanções podem assumir a forma de prisão, de multas e confisco dos benefícios, bens e valores advindos direta ou indiretamente do crime, sem prejuízo dos direitos de terceiros de boa-fé.

3. Para a escolha e a determinação da gravidade da sanção, os Estados-Partes levam em consideração especialmente os seguintes critérios:

a) Os benefícios econômicos advindo da infração, incluindo nesse caso as economias que puderam resultar da não adoção de medidas de proteção ambiental;

b) A posição hierárquica do autor da infração, o fato de que ele tenha cometido o crime no âmbito das atividades de uma pessoa jurídica ou o seu estatuto de funcionário público;

c) A pronta reparação dos danos e a indenização das vítimas;

d) O caráter organizado do crime.

4. A reparação de danos toma formas tais como:

a) Medidas de restauração ambiental,

b) Reparação por danos materiais e morais,

c) Programas de conformidade,

d) Provisionamento do Fundo para o meio ambiente,

e) Medidas de desenvolvimento local,

f) E, de acordo com as circunstâncias, medidas de reparação simbólica adaptadas à dimensão cultural do dano ambiental, que podem se expressar em pedidos de desculpas às comunidades locais.

\section{Artigo 7: Sanções contra as pessoas morais}

1. Os Estados-Partes adotam as medidas necessárias para punir, de maneira eficaz, proporcional e dissuasiva as pessoas morais reconhecidamente culpadas do crime de ecocídio e para garantir a reparação dos danos ambientais e a indenização das vítimas.

2. Os Estados-Partes adotam as medidas necessárias para punir, de maneira eficaz, proporcional e dissuasiva as pessoas morais reconhecidamente culpadas do crime de ecocídio. Em particular, os Estados-Partes consideram estabelecer as sanções seguintes:

a) Multas; 
b) Proibições, notadamente:

- A dissolução da pessoa jurídica;

- O encerramento temporário ou definitivo dos locais ou estabelecimentos da pessoa jurídica;

- A suspensão, temporária ou definitiva, do todo ou de Parte da atividade da pessoa jurídica no exercício daquela foi cometida, favorizada ou dissimulada a infração;

- A retirada de licenças, autorizações ou concessões;

- A proibição de receber subsídios e financiamentos públicos e de contratar com a administração pública.

c) Publicação da condenação. Quando há uma pluralidade de vítimas não identificadas, a publicação deve garantir que elas estejam conscientes do seu direito à indemnização;

d) Nomeação de um mandatário de justiça, a fim de que a pessoa jurídica adote as medidas organizacionais de natureza a prevenir novos crimes contra o meio ambiente ou que ela ele execute com diligência as medidas de reparação ou indenização.

3. A reparação de danos assume, notadamente, a forma de:

a) Medidas de restauração ambiental,

b) Reparação por danos materiais e morais,

c) Programas de Compliance,

d) Provisionamento do Fundo para o Meio Ambiente,

e) Medidas de desenvolvimento local,

f) E, dependendo das circunstâncias, de medidas de reparação simbólica adaptadas à dimensão cultural de danos ambientais, que podem assumir a forma de um pedido de desculpas para as comunidades afetadas.

4. Os Estados-membros adotam as medidas necessárias para impedir que as sanções ou as consequências danosas que delas decorrem possam ser garantidas.
Artigo 8 - Critérios de determinação da sanção das pessoas jurídicas

1. Para a escolha e a determinação da sanção, convém priorizar a reparação do dano e a indenização das vítimas.

2. Nos casos em que a multa possa comprometer a solvência da pessoa jurídica, a segurança dos empregos ou a reparação dos danos, os Estados-Partes podem fornecer a possibilidade de parcelar o pagamento. Nesses casos e, em conformidade com o direito interno, eles poderão, também, dar prioridade para a reparação do dano pela pessoa jurídica autora da infração.

3. Os Estados-Partes levarão em conta os seguintes critérios para a escolha e a determinação da gravidade da pena:

a) Os benefícios econômicos da infração;

b) Os benefícios econômicos da infração, incluindo nesse caso as economias que resultaram da falta de adoção de medidas de proteção ambiental;

c) A ausência ou a insuficiência de medidas de controles internos que teriam permitido a prevenção da infração;

d) A reiteração de infrações contra o meio ambiente no âmbito da ou pela pessoa jurídica. Para este fim, serão consideradas as sanções impostas às pessoas morais por outras autoridades;

e) A natureza organizada do crime;

f) A colaboração da pessoa jurídica no processo penal, em particular no estabelecimento da responsabilidade;

g) A reparação imediata dos danos e a assistência às vítimas;

h) A adoção imediata de medidas de controle interno para destinadas a prevenir infrações similares.

4. A dissolução da pessoa jurídica e o encerramento definitivo das suas instalações ou atividades só serão pronunciados se a pessoa jurídica tiver sido criada para cometer os fatos incriminados ou quando ela será considerada como parte de um grupo criminoso organizado, tal como definido no Convenção das Nações Unidas contra o Crime Organizado Transnacional. 


\section{Artigo 9 - Confisco e apreensão}

1. Os Estados-Partes devem adotar, na medida do possível em relação ao seus sistemas jurídicos nacionais, as medidas necessárias para permitir a confisco:

a) Do produto do crime derivado de infrações previstas na presente Convenção ou de bens cujo valor corresponda ao desse produto. $\mathrm{O}$ produto do crime também inclui as economias que resultam da não adoção de medidas de proteção ambiental;

b) Dos bens, equipamentos ou outros instrumentos utilizados ou destinados a serem utilizados na prática das infrações previstas na presente Convenção.

2. Os Estados-Partes adotam as medidas necessárias para permitir a identificação, a localização, o congelamento ou a apreensão dos elementos mencionados no parágrafo 1 do presente artigo, a fim de um eventual confisco.

3. Se o produto do crime tiver sido transformado ou convertido, no todo ou em parte, em outros bens, eles estão sujeitos às medidas referidas neste artigo no lugar do produto mencionado.

4. Se o produto do crime tiver sido misturado com bens adquiridos legalmente, esses bens, sem prejuízo de todos os poderes de congelamento ou de apreensão, podem ser confiscados até ao valor estimado do produto com o qual tenha sido misturado.

5. As receitas ou outros benefícios obtidos com o produto do crime, os bens nos quais o produto tenha sido transformado ou convertido ou os bens com os quais tenha sido misturado, podem também ser objeto das medidas referidas no presente artigo, da mesma maneira e na mesma medida que o produto do crime.

6. Para efeitos deste artigo e do artigo 13 da presente Convenção, cada Estado-Parte habilita seus tribunais ou outras autoridades competentes para ordenarem a produção ou a apreensão de documentos bancários, financeiros ou comerciais. Os Estados-Partes não podem invocar o sigilo bancário para recusar de dar cumprimento às disposições do presente parágrafo.

7. A interpretação das disposições do presente artigo não deve, em nenhum caso, violar os direitos de terceiros de boa fé.
8. Nenhuma disposição do presente artigo viola o princípio segundo o qual as medidas que são visadas são definidas e executadas em conformidade com o direito interno de cada Estado-Parte e segundo as disposições desse direito.

\section{Artigo 10 - Competências nacionais}

1. Cada Estado-Parte adota as medidas necessárias para estabelecer sua competência relativa ao crime de ecocídio nos casos seguintes:

a) Quando os fatos tiverem sido cometidos em todo o território sob a jurisdição desse Estado; ou

b) Quando o resultado da infração é realizado em todo o território sob a jurisdição desse Estado; ou

c) Quando a infração for cometida a bordo de um navio de seu pavilhão ou a bordo de uma aeronave matriculada no seu direito nacional no momento em que a infração é cometida; ou

d) Quando a infração for cometida por um dos seus nacionais; ou

e) Quando a infração for cometida por uma pessoa jurídica que tenha a sua sede ou o sua atividade principal ou seu principal centro administrativo no seu território; ou

f) Quando a infração for cometida contra um dos seus nacionais e que o Estado o considere apropriado.

2. Cada Estado-Parte adota, igualmente, as medidas que sejam necessárias para estabelecer sua competência nos casos em que o suposto autor de um crime de ecocídio encontra-se em seu território e que ele não o extradite, nos termos do artigo 15, para qualquer um dos Estados-Partes que tenham estabelecido sua competência de acordo com o parágrafo 1 .

3. Quando mais de um Estado-Parte declara-se competente em relação a um crime de ecocídio, os Estados-Partes interessados se esforçam para coordenar suas ações de forma adequada, em especial no que diz respeito às condições de engajamento de persecução e de modalidades de assistência jurídica mútua.

4. Sem prejuízo das normas do direito internacional geral, a presente Convenção não exclui o exercício de 
qualquer competência penal estabelecida por um Estado-Parte, em conformidade com seu direito interno.

\section{Artigo 11 - Investigação e persecução penal}

1. Se considerar que as circunstâncias justificam, depois de analisar as informações de que dispõe, qualquer Estado-Parte em cujo território se encontra uma pessoa suspeita de ter cometido um crime de ecocídio, assegura a detenção dessa pessoa ou toma todas as outras medidas legais para garantir sua presença. Essa detenção e essas outras medidas devem estar em conformidade com a legislação desse Estado; elas podem ser mantidas somente durante o tempo que for necessário para permitir o estabelecimento de um processo penal ou de um processo de extradição.

2. Tal Estado procede imediatamente a uma investigação preliminar com vistas a estabelecer os fatos.

3. Qualquer pessoa detida em virtude do parágrafo 1 deste artigo poderá se comunicar, imediatamente, com o representante competente mais próximo do Estado da sua nacionalidade ou, se for um apátrida, com o representante da Estado em que resida habitualmente.

4. Quando um Estado detém uma pessoa em custódia nos termos das disposições deste artigo, ele notifica, imediatamente, a detenção e as circunstâncias que a justificam aos Estados referidos no parágrafo 1 do artigo 10. O Estado que procede à investigação preliminar prevista no parágrafo 2 do presente artigo deve comunicar rapidamente as suas conclusões aos citados Estados e indicará se pretende exercer sua competência.

5. Este Estado deve comunicar essas informações o mais rapidamente possível ao Procurador Internacional do meio ambiente previsto no artigo 17.

\section{Artigo 12 - Participação da sociedade civil}

Cada Estado-Parte visa favorizar, em conformidade com seu direito interno, a informação da sociedade civil e sua participação aos processos penais relativos a crimes de ecocídio, de um grupo, de uma fundação ou uma associação que, de acordo com seu estatuto, tem por objetivo a proteção do meio ambiente.

\section{Artigo 13 - Extraditar ou processar}

1. O Estado-Parte, sobre o território e sob a jurisdição em que se encontra o presumível autor de um crime de ecocídio, se não o extraditar, submete o caso às suas autoridades competentes para o exercício da ação penal.

2. Essas autoridades tomarão sua decisão nas mesmas condições que para qualquer outra infração de direito comum de natureza grave nos termos do direito desse Estado.

3. Toda pessoa processada por crime de ecocídio beneficia da garantia de um tratamento equitativo em todas as fases do processo.

\section{Artigo 14 - Extradição}

1. O crime de ecocídio é automaticamente considerado como passível de extradição em qualquer tratado de extradição concluído entre os Estados-Partes antes da entrada em vigor da presente Convenção. Os Estados-Partes comprometem-se a incluir essa infração como caso de extradição em todo tratado de extradição futuramente concluído.

2. Um Estado-Parte que condiciona a extradição à existência de um tratado tem a faculdade, quando receber um pedido de extradição de outro Estado-Parte com o qual não está vinculado por um tratado de extradição, de considerar esta Convenção como a base jurídica para a extradição relativamente ao crime de ecocídio. A extradição estará sujeita às demais condições previstas pela legislação do Estado requerido.

3. Os Estados-Partes que não condicionam a extradição à existência de um tratado reconhecendo o crime de ecocídio como caso de extradição entre eles, sem prejuízo das condições previstas pela legislação do Estado requerido.

4. Se necessário, o crime de ecocídio é considerado, para efeitos de extradição entre os Estados-Partes, como cometido tanto no lugar de sua perpetração como no território dos Estados que estabeleceram sua competência de acordo com o artigo 10.

5. Para fins de extradição ou assistência jurídica mútua entre os Estados-Partes, o crime de ecocídio não pode ser considerado como uma infração política, 
como uma infração conexa à uma infração política ou como uma infração inspirada por motivos políticos. Por conseguinte, um pedido de extradição ou de assistência jurídica mútua com base em tal infração não poderá ser recusada pela simples razão de que se trata de uma infração política, uma infração conexa a uma infração política ou uma infração inspirada por motivos políticos.

\section{Artigo 15 - Assistência jurídica mútua}

1. Os Estados-Partes acordam, mutualmente, uma ampla assistência jurídica para as investigações, os processos e os procedimentos judiciais relativos ao crime de ecocídio.

2. A assistência jurídica mútua é baseada no princípio do reconhecimento mútuo das sentenças e decisões judiciais dos Estados Partes.

3. A mais ampla assistência jurídica mútua possível é concedida, desde que as leis, tratados, acordos e arranjos pertinentes do Estado-Parte requerido a permita, quando das investigações, processos e procedimentos judiciais relativos a infrações pelas quais uma pessoa jurídica possa ser passível de responsabilidade no Estado-Parte requerente, em conformidade com o artigo 5 da presente Convenção.

4. A assistência jurídica mútua é realizada, também, em processos por fatos puníveis nos termos do direito nacional do Estado-Membro requerente ou do Estado-Membro requerido, ou ambos, a titulo de violações das regras investigadas pelas autoridades administrativas, cuja decisão pode gerar um processo perante um tribunal competente, notadamente em matéria penal.

5. Os Estados-Partes poderão invocar a falta de dupla incriminação para recusar dar seguimento a um pedido de assistência nos termos do presente artigo. $\mathrm{O}$ Estado-Parte requerido poderá, contudo, quando considerar apropriado, prestar essa assistência, na medida em que ele decide a seu critério, independentemente do fato que a conduta possa constituir ou não uma infração nos termos do direito nacional do Estado-Parte requerido.

6. Cada Estado-Parte designa uma autoridade central que tem a responsabilidade e o poder de receber as demandas de assistência jurídica mútua e, seja executá-las, seja transmiti-las às autoridades competentes para execução. As autoridades centrais garantem a execução ou a transmissão rápida e em adequada forma das de- mandas recebidas.

7. As demandas são endereçadas por escrito ou, se possível, por todo outro meio que possa produzir um documento escrito, em uma língua aceitável para o Estado-Parte requerido, nas condições que permitem a esse Estado de estabelecer sua autenticidade. Em caso de urgência e se os Estados-Parte convêm, as demandas podem ser feitas oralmente, mas devem ser confirmadas sem prazo por escrito.

8. Toda demanda é executada em conformidade com o direito interno do Estado-Parte requerido e, na medida em que ela não contrarie o direito interno desse Estado e quando é possível, de acordo com os procedimentos especificados na demanda.

9. A assistência jurídica mútua pode ser refusada:

a) Se a demanda não é feita em conformidade com as disposições do presente artigo;

b) Se o Estado Parte requerido estima que a execução da demanda é suscetível de causar um prejuízo à sua soberania, à sua segurança, à sua ordem pública ou a outros interesses essenciais;

c) Caso o direito interno do Estado Parte requerido proíba suas autoridades de tomar as medidas demandadas tratando-se de uma infração análoga tendo sido objeto de uma investigação, de um processo ou de um processo judiciário no quadro de sua própria competência;

d) Caso ele seria contrário ao sistema jurídico do Estado-Parte requerido relativamente à assistência jurídica mútua de aceitar a demanda.

10. Toda recusa de assistência jurídica mútua deve ser motivada. Antes de recusar um pedido de assistência ou adiar sua execução, nos termos do parágrafo 11, o Estado-Parte requerido deve estudar com o Estado-Parte requerente a possibilidade de conceder a assistência sob reserva das condições que ele considerar necessárias. Se o Estado-Parte requerente aceitar a assistência jurídica mútua sujeita a condições, ele deverá respeitá-las.

11. O Estado-Parte requerente deverá executar a demanda de assistência jurídica mútua o mais rapidamente possível e deve levar em conta, na medida do possível, todos os prazos sugeridos pelo Estado-Parte requerente e que estão motivados de preferência na demanda. A assistência pode ser adiada pelo Estado-Parte requerido pelo motivo que ela interfere em uma investigação 
em curso, uma ação judicial ou um processo judicial em curso.

\section{Artigo 16 - Cooperação internacional}

1. Os Estados-Partes concordam, em conformidade com as disposições dos instrumentos internacionais pertinentes em matéria de cooperação internacional em matéria penal e com seu direito interno, com a mais ampla cooperação em investigações e processos judiciais relacionados com o crime de ecocídio.

2. Os Estados-Partes, na investigação e na persecução do crime de ecocídio, cooperam, ativamente, com o órgão do Procurador internacional previsto no artigo 17.

\section{Artigo 17 - Competência do Procurador Interna- cional do Meio Ambiente}

1. A Assembleia dos Estados-Partes elege por 5 anos um Procurador Internacional do meio ambiente independente, complementar às autoridades judiciais nacionais.

2. O Procurador Internacional é competente para investigar e reunir provas relativas a supostos atos de ecocídio levadas ao seu conhecimento, pelas autoridades nacionais dos Estados-Partes, por instituições regionais e internacionais interessadas na luta contra o criminalidade ambiental, pela sociedade civil ou pelo GREEN.

3. Os Estados-Partes designam um procurador nacional como correspondente do Procurador Internacional do meio ambiente.

4. O Procurador Internacional do Meio Ambiente presta apoio às autoridades nacionais e contribui para a coordenação das investigações e dos procedimentos penais.

\section{Artigo 18 - Criação de um Tribunal Penal Inter- nacional do Meio Ambiente}

Os Estados-Partes cooperam a fim de criar um Tribunal Penal Internacional para o Meio Ambiente, complementar das jurisdições nacionais, competente para julgar o crime de ecocídio.

\section{Capítulo 2: Medidas preventivas}

\section{Artigo 19 - A cooperação internacional em ma- téria de prevenção}

1. Os Estados-Partes cooperam para prevenir o crime de ecocídio, adotando todas as medidas possíveis, especialmente, se necessário, adaptando sua legislação nacional, para evitar e impedir a preparação em seus respectivos territórios de infrações a serem cometidas no interior ou fora do seu território.

2. Os Estados-Partes cooperam, também, para a prevenção do crime ecocídio, por meio da troca de informações precisas e verificadas em conformidade com sua legislação interna e por meio da coordenação de medidas administrativas e de outras medidas tomadas.

3. Os Estados-Partes podem trocar informações pelo intermédio de instituições regionais e internacionais interessadas na luta contra a criminalidade ambiental, incluindo a Interpol, a Europol e o Escritório das Nações Unidas sobre drogas e crime.

4. Os Estados-Partes dispensam ou reforçam a formação adequada dos profissionais pertinentes que tratam de autores e suspeitos de um crime de ecocídio e de suas vítimas.

5. Os Estados-Partes se esforçam para sensibilizar o público quanto à existência, às causas e à gravidade da criminalidade ambiental e à ameaça que ela representa. Eles podem fazê-lo, se necessário, por intermédio dos meios de comunicação social e pela adoção de medidas destinadas a promover a participação do público nas atividades de prevenção e de repressão desse crime.

6. Os Estados-Partes informam o Secretário da presente Convenção o nome e o endereço da autoridade ou das autoridades que podem ajudar as outras Partes a desenvolver as medidas de prevenção do crime de ecocídio.

7. Os Estados-Partes colaboram, conforme sua conveniência, entre eles e com as instituições regionais e internacionais competentes, para desenvolver e promover 
as medidas visadas pelo presente capítulo.

\section{Artigo 20 - Competência do Grupo de Pesqui- sa e de Investigação para o Meio Ambiente37 (GREEN)}

1. O Grupo de Pesquisa e de Investigação para o Meio Ambiente (GREEN) procede à constatação dos fatos materiais suscetíveis de corresponder à definição do crime de ecocídio e à formulação de opiniões sobre a criminalidade ambiental internacional.

2. O GREEN age com base na demanda de um ou mais Estados-Partes, do Secretariado da Convenção, do Procurador Internacional do Meio Ambiente, de todas as outras instituições encarregadas de lidar com os mais graves crimes ambientais ou com base em um comunicação da sociedade civil.

3. O GREEN é composto por 20 membros eleitos pelos Estados-Partes, de acordo com uma distribuição geográfica equitativa. Os membros do GREEN exercem suas funções a título individual. Eles devem gozar de caráter jurídica elevado e beneficiar de experiência reconhecida em matéria ambiental.

4. O GREEN pode solicitar aos Estados-Partes e às instituições nacionais, regionais e internacionais competentes todas as informações e toda a assistência que considerar necessárias, a fim de lhe permitir-lhe cumprir sua missão.

5. O GREEN pública, anualmente, um relatório de atividades.

\section{Capítulo 3: Aplicação da Convenção}

\section{Artigo 21 - Proteção da soberania}

1. Os Estados-Partes cumprirão as obrigações decorrentes da presente Convenção em conformidade com os princípios de igualdade soberana e de integridade territorial dos Estados, assim como da não ingerência nos assuntos internos de outros Estados.

2. Nenhuma disposição da presente Convenção autoriza qualquer Estado-Parte a exercer, no território de outro Estado-Parte, uma competência ou funções

37 Em francês: Groupe de Recherche et d'Enquête pour l'Environnement (GREEN). exclusivamente reservadas às autoridades desse outro Estado-Parte por seu direito interno.

\section{Artigo 22 - Implementação da Convenção}

1. Cada Estado-Parte adota as medidas necessárias, incluindo legislativas e administrativas, de acordo com os princípios fundamentais de sua legislação interna, para garantir o cumprimento das suas obrigações em virtude da presente Convenção.

2. Cada Estado-Parte poderá adotar medidas mais estritas ou mais severas do que as previstas pela presente Convenção para prevenir e punir os crimes internacionais mais graves contra o meio ambiente.

3. As disposições da presente Convenção são aplicadas e interpretadas de acordo com as regras do direito internacional geral e os princípios do direito internacional do meio ambiente, notadamente o princípio de responsabilidades comuns, mas diferenciadas.

\section{Artigo 23 - Exame do cumprimento das disposi- ções}

1. A Assembleia dos Estados-Partes adota, por consenso, disposições de caráter não conflituoso, de natureza não judicial e consultiva para examinar o cumprimento das disposições da presente Convenção.

2. Essas disposições deverão permitir uma apropriada participação do público e prever a opção de se admitirem comunicações de membros do público sobre questões relacionadas à presente Convenção.

3. O procedimento adotado por consenso para o exame do cumprimento das disposições da presente Convenção aplica-se sem prejuízo do processo de resolução de litígios previstos no artigo 26. Sempre que possível, as Partes deverão utilizar procedimentos preliminares relativos ao cumprimento antes de recorrer a mecanismos de solução de disputas.

\section{Artigo 24 - Solução de controvérsias}

1. Se surgir uma controvérsia entre duas ou mais Partes quanto à interpretação ou a aplicação dessa Convenção, elas devem se esforçar para resolvê-la pela via da negociação ou por qualquer outro meio de resolução de disputas que elas considerarem aceitável. Além disso, 
as Partes procuram a melhor solução para o estado do meio ambiente e o respeito de seus direitos, pela implementação anterior e, na medida do que é apropriado, do procedimento de exame do respeito das disposições previsto no artigo 25.

2. Quando uma Parte assina, ratifica, aceita, aprova ou adere à presente Convenção, ou em qualquer momento posterior, ela pode declarar por escrito ao depositário que, no caso de disputas não foram resolvidas em conformidade com o parágrafo 1 acima, ela aceita como obrigatório um dos dois ou ambos os meios de solução de controvérsias abaixo em suas relações com qualquer Parte que aceite a mesma obrigação:

a) A submissão da controvérsia à Corte Internacional de Justiça;

b) A submissão da controvérsia à arbitragem;

3. Se as Partes na controvérsia aceitarem os dois meios de solução de controvérsias referidos no parágrafo 2 acima, a controvérsia poderá ser submetida apenas à Corte Internacional de Justiça, a menos que elas acordem o contrário.

\section{Artigo 25 - Medidas cautelares}

1. Se uma corte, um tribunal ou um órgão responsável pelo exame do respeito da Convenção, regularmente invocado por uma controvérsia ou uma situação que considere, prima facie, que tem jurisdição sobre a controvérsia ou sobre a situação, em conformidade com a presente Convenção, esse tribunal ou esse órgão pode prescrever quaisquer medidas cautelares que considere apropriadas à circunstância a fim de evitar o grave prejuízo ambiente ou para preservar os direitos respectivos das Partes em litígio, aguardando a decisão final.

2. As medidas cautelares podem ser modificadas ou retiradas no momento em que as circunstâncias que as justificavam mudem ou deixem de existir.

3. Medidas cautelares podem ser prescritas, modificadas ou retiradas em virtude do presente artigo pela demanda de uma Parte à controvérsia ou de todo membro do público interessado e habilitado a apresentar comunicações. As medidas cautelares podem ser prescritas, modificadas ou retiradas somente depois que a possibilidade de ser ouvido tenha sido dada às Partes.

4. A corte, o tribunal ou o órgão responsável pelo cumprimento da Convenção notifica imediatamente as diferentes Partes à controvérsia de qualquer medida cautelar ou qualquer decisão de modificação ou de retirada e, se considerar apropriado, quaisquer outras pessoas que julgar interessada.

5. Enquanto aguarda a constituição de um tribunal arbitral para apreciar a controvérsia nos termos do artigo 26, qualquer órgão jurisdicional designado de comum acordo pelas Partes ou, na falta de acordo no prazo de duas semanas a contar da data do pedido de medidas cautelares, a Corte Internacional de Justiça pode prescrever, modificar ou revogar medidas cautelares em conformidade com o presente artigo, se considerar que, prima facie, o tribunal a ser constituído teria jurisdição e se ela estima que a urgência da situação exige. Uma vez constituído, o tribunal que julgará a controvérsia, de acordo com os parágrafos 1 a 4, pode modificar, revogar ou confirmar essas medidas cautelares.

6. As Partes à controvérsia se conformam sem demora a todas as medidas cautelares prescritas em virtude deste artigo.

\section{Capítulo 4: Disposições Finais}

$\mathrm{Na}$ ausência de especificidade própria em matéria de crime de ecocídio, as disposições finais não serão na presente objeto de desenvolvimentos. 
Para publicar na Revista de Direito Internacional, acesse o endereço eletrônico www.rdi.uniceub.br ou www.brazilianjournal.org.

Observe as normas de publicação, para facilitar e agilizar o trabalho de edição. 